MT-DP - 2006/7

\title{
Skill diffusion by temporary migration? Returns to Western European working experience in the EU accession countries
}

ANNA IARA 


\section{Discussion papers \\ MT-DP - 2006/7}

Institute of Economics, Hungarian Academy of Sciences

KTI/IE Discussion Papers are circulated to promote discussion and provoke comments. Any references to discussion papers should clearly state that the paper is preliminary. Materials published in this series may be subject to further publication.

Skill diffusion by temporary migration? Returns to Western European working experience in the EU accession countries

Anna Iara,

The Vienna Institute of International Economic Studies (wiiw) and

Center for European Integration Studies (ZEI), University of Bonn. Address: wiiw, Oppolzergasse 6, A - 1010 Vienna.

iara@wiiw.ac.at

ISBN $9639588 \quad 78 \quad 4$

ISSN $1785-377 \mathrm{X}$

Publisher:

Institute of Economics, Hungarian Academy of Sciences 


\title{
Elősegíti-e az ideiglenes migráció a szaktudás terjedését? A nyugat-európai munkatapasztalat hozadéka az EU-hoz csatlakozó államokban
}

\author{
Iara Anna
}

\section{Összefoglaló}

Európában növekszik az ideiglenes vándorlás jelentősége. Egy fejlettebb és magasabb bérszínvonalú országban szerzett munkatapasztalat javíthatja egy ideiglenes migráns szaktudását. A külföldön szerzett emberi tőkével, amelyet visszatértekor magával hoz a kibocsátó országba, elősegítheti a szaktudás nemzetközi terjedését és a kibocsátó ország felzárkózását. E tanulmány elsőként szolgáltat tapasztalati eredményeket ezen hipotézis alátámasztására a 2003-as ifjúsági Eurobarometer keresztmetszeti adataira támaszkodva, kelet-nyugati megközelítésben.

Tárgyszavak:

Kelet-, Közép- és Délkelet-Európa, ideiglenes vándorlás, bérhozam, szaktudás-terjedés 


\title{
Skill diffusion by temporary migration? Returns to Western European working experience in the EU accession countries"
}

\author{
Anna Iara $^{* *}$
}

August 2006

\begin{abstract}
Temporary migration is of growing significance in Europe. Upon migration to a country with higher technological development that typically coincides with positive wage differentials, temporary migrants may upgrade their skills by learning on the job and subsequently import the newly acquired human capital to their source country, thus adding to international know-how diffusion and the catching up of the respective economy. This paper is the first to provide supportive evidence of this hypothesis in a cross-country East to West European perspective, using the 2003 Youth Eurobarometer dataset.
\end{abstract}

JEL: J61, J31, O15

Keywords: Central and Eastern Europe, return migration, wage premium, skill diffusion

\footnotetext{
* This research has received financial support from the GDN-SEE network. I thank Jörg Breitung, Edward Christie, Vladimir Gligorov, Milena Jovicic, Iulia Traistaru, Danny Sriskandarajah, Robert Stehrer, Alessandra Venturini, Alan Winters, Guntram Wolff, and the participants of the GDN workshops in Vienna, July 2005 and May 2006, and in St Petersburg, January 2006, for discussion and advice.

** The Vienna Institute of International Economic Studies (wiiw) and Center for European Integration Studies (ZEI), University of Bonn. Address: wiiw, Oppolzergasse 6, A - 1010 Vienna. Email: iara@wiiw.ac.at.
} 


\section{$1 \quad$ Introduction}

Migration has become a highly debated issue both in sending and receiving countries. Typically, the former are less developed, while the latter are mature industrialised economies. Among these, most of the EU member states have adopted a restrictive regime towards immigration, even - albeit temporarily - against labour movement from the new EU members. Decreasing public support for immigration in many destination countries on the one hand, concerns of an exodus of the better skilled from source countries on the other, and, finally, growing migratory pressure created by individual desires are urgeing for a taxation of various immigration policy instruments. This paper contributes to this debate by providing evidence on the returns to working experience in Western Europe in Eastern European labour markets. The focus is hence on temporary or return migration of labour in an East to West European context, adopting a source country perspective.

Empirical evidence shows that return migration has been a constitutive part of international migratory flows throughout the $20^{\text {th }}$ century (Constant and Massey, 2002). In Western Europe specifically, return migration from Central Europe has grown in size in the 1990s (International Organization for Migration 2005: 145). Nevertheless, only recently has academic interest in migration become dedicated to migrants' possibilities of return. Existing work has been focused on the decision to re-migrate. Borjas and Bratsberg (1996) were among the first to study determinants of return migration both theoretically and empirically. Extending the standard Roy model ${ }^{1}$ framework of mobility decisions to allow for reversibility, they show that return migration accentuates the selectivity of international mobility: the permanent stayers in the host country are "the best of the best" or "the worst of the worst" in the presence of positive or negative selection respectively. Dustmann and Kirchkamp (2000) furthered analytical thinking on return migration by modelling the simultaneous choice of migration duration and after-return employment status. As concerns the economic performance of returning migrants in their original country, economic analysis has so far focused on entrepreneurial activities of the returning migrants. Among others, empirical work has documented the higher probability of self-employment among returning migrants relative to the non-migrating population. Also, it has been hypothesised that a foreign working experience may offer the opportunity to accumulate savings to the migrant that she would use to overcome capital constraints to entrepreneurship upon return.

In a partial equilibrium perspective, post-return differential earnings of returning migrant workers may be significant to the migrant's home economy. In this context, we argue that a work stay in a more advanced economy (as it is characteristic of economic migration) may equip the individual

\footnotetext{
${ }^{1}$ Roy (1951) has provided a general framework for the study of self selection in labour mobility based on costs and benefits of the potential move. We will elaborate on the Roy model in more detail in section 2.
} 
with either advanced technological knowledge or specific cultural knowledge that is likely to contribute to the competitiveness of the firm employing her and thus receive differential rewards back in the home economy. In this sense, temporary migration may contribute to international knowledge diffusion and increased international economic integration (via tightening international ties).

In spite of the significance of such potentials for knowledge diffusion, we know of no more than three studies of temporary migrants' post-return earnings performance, each looking at a single country. Co, Gang, and Yun (1999) study differential earnings of Hungarian workers with recent foreign working experience, using pooled household panel data of 1993 and 1994. In a maximum likelihood estimation framework, they account for selection both into labour force participation and going abroad. Their analysis reveals positive returns to women's foreign working experience from OECD countries, but no such returns for women who returned from non-OECD countries, and for men. They also find evidence for positive selection of working men into the foreign working experience and negative selection for women, respectively. Barrett and O'Connell (2001) investigate differential earnings of temporary migrants back to Ireland, using survey data of 1992 college graduates. Information in this survey on reasons for emigration and return allows them to distinguish among others between human capital investment oriented and consumption, i.e. adventure oriented temporary migration. Estimating OLS wage regressions, they find a wage premium for men returning from labour market-related moves of 15 per cent, but no premium either for women or for men back from consumption oriented stays abroad. Their attempt to account for selectivity into migration by the standard Heckman correction procedure does not provide significant results. Finally, de Coulon and Piracha (2003) study the wage premium of returning migrants to Albania with survey data of 1998. They provide maximum likelihood estimates of earnings functions for migrants and stayers respectively conditional on the decision to migrate. In addition, they look at the observed and counterfactual wage distributions for migrants and stayers, using semiparametric techniques. Their analysis provides evidence of negative selection among Albanian temporary migrants, and of significant differences in migrants' and non-migrants' earnings functions. In particular, according to their results, stayers are rather rewarded for education and age (experience), whereas migrants' average remuneration rather draws upon better career positions and a higher self-employment premium.

Our research provides evidence of the returns to working experience of young temporary migrants obtained in any of the countries of the EU-15 plus Norway, Switzerland or Iceland upon return to the 13 pre-2005 EU candidate countries, based on data from the 2003 Central and Eastern European Youth Eurobarometer. We contribute to the understanding of the labour market effects of temporary migration by providing the first cross-country study on premia to work experience abroad. This is an advantage for migration has proven to have strong country-specific characteristics that prohibit drawing general conclusions from single country studies (Krieger 2004: 71). The findings of the above studies on East to West European migration may be particularly nongeneric, for Co et al. 
look at a country in the first years of transition since which wage determination in Hungary has undergone substantial adjustments, while the migration patterns of Albania may be far from representative of Eastern European countries, in particular due to the scale of Albanian temporary migration involving around one third of the labour force, as well as negative selectivity (de Coulon and Piracha, 2003). With our broad coverage of source and destination countries, we are able account for country specific effects as far as cross-section data permit. We investigate the premium to return migration from Western Europe to young males from EU accession countries appyling the endogenous switching regression methodology that allows the consideration of selection effects both concerning the choice to work or not, and the choice to go abroad or not to do so. We find empirical evidence of characteristic differences in the earnings patterns of movers and stayers among the Eastern European young men and, specifically, the former to be able to claim by around 30 per cent higher earnings than the latter. Our results on selection effects in going or not going abroad, however, are ambiguous.

Concerning the type of temporary work related stays in Western Europe covered by our data, we can, unfortunately, only speculate. Prior to EU accession, citizens of the future EU members were not allowed to assume legal work in the member states of the European Economic Area (EEA) except within specific arrangements. However, such arrangements offered a variety of facilities for temporary employment. In the 1990s, most EEA members have granted specific temporary work and training opportunities to EU accession countries' nationals within bilateral labour agreements, among others with the purpose of enhancing labour mobility and economic integration (Bobeva and Garson, 2004). Such agreements covered seasonal employment (in areas with large temporary fluctuations of labour demand, such as agriculture, catering, and construction), project-based employment (via a work assignment to a company), guest worker schemes (offering skilled professional training opportunities), and traineeship and apprenticeship programmes respectively (see Bobeva and Garson, 2004, and OECD 2004, Annex 1a). For the case of Hungary, Hárs (2003) presents a unique evaluation of a dataset on individuals who participated in bilateral programmes with Germany, Austria and Switzerland in 2001. She finds that 40 per cent of the 1877 participants of traineeship, frontalier and seasonal worker schemes in these countries aged 24 and younger were trainees. Besides, she does not find support for the claim that the work performed by temporary migrants abroad is typically below their skill level or domestic work status. The relative importance of various bilateral work programmes varies by destination country. ${ }^{2}$ Still, the above findings illustrate the availability of opportunities for skill enhancement available to young nationals of the EU accession countries in Western Europe. In addition to work schemes specified in bilateral agreements, legal opportunities for temporary work abroad are provided by sector-based work schemes that are not restricted to citizens of specific

\footnotetext{
2 E.g., Kaczmarczyk and Okólski (2005) report that 76 per cent of Polish nationals working abroad in the late 1990s were seasonal workers in Germany, while in Hárs' sample of Hungarians in Germany, Austria and Switzerland, considerably less -58 per cent - are seasonal workers.
} 
countries (see Bobeva and Garson, 2004). Such schemes were set up for highly skilled migrants in specific sectors as well (e.g. for ICT workers in Germany). Assuming that temporary work abroad at higher qualification levels typically covers longer work stays unless it is part of a trainee programme, we consider it less likely that individuals aged 24 and less have participated in sector-based schemes for the higher skilled abroad. A further possibility to work abroad for that can rather be expected to provide for skill enhancement is the right granted to foreign students to assume work during their study abroad, as e.g. in the Netherlands and France (see OECD, 1998). Finally, Western European work related stays reported in our sample may relate to illegal labour. This type of activity can again be expected to have a rather low skill content. Based on these considerations, we conclude that in 2003 various opportunities existed for young Eastern European citizens to assume work abroad. A major part of such opportunities appears less suited to provide for the acquisition or enhancement of specific or particularly high skills. Still, work experience abroad may have sufficiently enhanced the human capital of a returning migrant to obtain a higher wage back home. This is what we empirically investigate in the present analysis. Unfortunately, our data do not allow to differentiate our econometric assessment by destination countries and their policies towards temporary foreign employment.

This paper is structured as follows. In the next section, we outline the analytical framework and discuss the methodology adopted. In section 3, we describe the dataset and present summary statistics. Section 4 offers the estimation results. Section 5 concludes.

\section{$2 \quad$ Analytical and methodological framework}

\subsection{Analytical framework}

We aim at empirically assessing the returns to working experience made in more developed countries by nationals of Eastern European countries. To this end we perform an endogenous switching regression analysis of standard wage equations accounting for individual and job characteristics as developed by Mincer.

More formally, we assume that individuals work equal hours that are normalised to one so that their earnings from work equal the hourly wage, $W$. Workers are remunerated for their human capital that can be decomposed to the individual's education, sector-specific knowledge, working experience, and an individual component that is observed to the employer but not to the researcher. Working experience specifically is valued for its training-on-the-job effect. Denoting working experience (i.e. training) by $T$, a vector of other variables (including a constant) by $X$, and the unobserved component by $\xi$, in a standard loglinear specification, individual wages are described by 
$w_{i}=X_{i}{ }^{\prime} \alpha+T_{i}{ }^{\prime} \psi+v^{\prime} \xi_{i}$

where $w=\log (W)$. The coefficients reflect how the employer valuates the human capital components of the individual.

Human capital from on-the-job training can be acquired in the home country of the worker, $H$, or a foreign country, $F$. Country $F$ is technologically more advanced. A worker from $H$ who receives training abroad has the opportunity to learn about specific technologies. A potential employer in $H$ may be particularly interested in hiring such a worker because her imported knowledge could add to the competitiveness of his firm. Therefore, the employer will remunerate working experience acquired in $F$ higher than domestic experience. However, working expience from the foreign country may also be regarded less valuable than domestic experience, notably if country $H$ lacks the conditions for the adaptation of the skills practiced in $F$, i.e. if production technologies are incompatibly different in the two countries. In addition to specific working experience, a work stay abroad may help the migrant develop further qualities $\gamma_{i}$ that are observable to, and appreciated by, the domestic employer but that are unobservable from standard survey data. ${ }^{3}$

With the above distinction between domestic and foreign working experience, the equation describing wages in country $H$ is

$$
w^{H}=X_{i}^{H} \cdot \alpha^{H}+\psi^{H} T_{i}^{H}+\phi^{H} T_{i}^{F}+\nu^{H} \xi_{i}+\gamma_{i}
$$

where $\psi$ and $\phi$ describe the valuation of domestic and foreign job-specific human capital acquired on the job respectively ${ }^{4}$. For non-migrant workers, $T_{i}^{F}=0$ and $\gamma_{i}=0$.

Consider a worker equipped with certain human capital characteristics including working experience $T_{0}^{H}$ acquired in her native country in $t=0$. For the next period, the worker may or may not emigrate. If she goes abroad, she obtain a salary amounting to

$w_{i l}^{F}=X_{i}^{F} \cdot \alpha^{F}+\phi^{F} T_{i 0}{ }^{H}+v^{F} \xi_{i}$

If she does not, her earnings are described by

$$
w_{i l}^{H}=X_{i}^{H} \cdot \alpha^{H}+\psi^{H} T_{i 0 i}{ }^{H}+v^{H} \xi_{i}
$$

Work abroad is possible for one period only. In this period, migrant worker has acquired additional experience $T_{l}^{F}$. If she remained in $\mathrm{H}$, in the same period she would have acquired further domestic experience $T_{l}^{H}$. In $t=2$, a returning migrant worker can expect a salary of

$$
w_{i 2}{ }^{H, M}=X_{i}{ }^{H} \cdot \alpha^{H}+\psi^{H} T_{i 0}{ }^{H}+\phi^{H} T_{i 1}{ }^{F}+\nu^{H} \xi_{i}+\gamma_{i}
$$

\footnotetext{
${ }^{3}$ An example of such qualities is assertiveness that may be better developed by those who have to establish their living conditions in a new environment than by those who remain with their everyday routines.

${ }^{4}$ We will refer to these skills as unobserved, noting that they are observed by the employer.
} 
while a stayer obtains

$w_{i 2}{ }^{H, S}=X_{i}{ }^{H} \cdot \alpha^{H}+\psi^{H}\left(T_{i 0}{ }^{H}+T_{i 1}{ }^{H}\right)+v^{H} \xi_{i}$

Indicating migrant workers by $m=1$ and stayers by $m=0$, we can collapse these equations into

$w_{i 2}{ }^{H}=X_{i}{ }^{H} \alpha^{H}+\psi^{H}\left(T_{i 0}+T_{i 1}\right)+m_{i}\left[\left(\phi^{H}-\psi^{H}\right) T_{i 1}+\gamma_{i}\right]+v^{H} \xi_{i}$

In sum, with the above assumptions, work stays abroad provide additional qualities to migrant workers that are expected to allow for differential remuneration as compared to non-migrant workers' skills. Part of these qualities is unobservable. We expect that the differential remuneration is positive, reflecting the transfer of superior knowledge from the technologically more advanced foreign country into the home country, if the latter has the necessary capacities to adapt this knowledge.

If stayers and movers do not differ by their unobserved characterisics $\xi$ and if no unobserved skills $\gamma$ are to be developed abroad, differential returns from foreign working experience described by the term $\left(\phi^{H}-\psi^{H}\right)$ in the above equation can be estimated in a simple OLS equation, accounting for migrants by a dummy variable interacted with working experience in $t=1$. However, if $\gamma \neq 0$, or if a worker's status regarding her foreign working experience is correlated with her unobserved human capital component $\xi$, the former is no longer exogenous and requires distinguished consideration.

Economic thinking of migration as laid down by Roy (1951) states that migration decisions are taken in response to the net expected benefit from the move: the individual will move if total gains net of the cost of the move are positive, and she will decline the opportunity otherwise. In this sense, in our application ${ }^{5}$ potential migrants have expected benefits from wage increments that consist of two components: first, the differential income wage earned during the stay abroad (that is typically higher in EU member states than in accession countries), and the differential returns to their foreign work experience and skills developed abroad. The former is the difference between (3a) and (3b):

$$
w_{i l}^{F}-w_{i l}^{H}=d w_{i l}=\left(X_{i}^{F} \cdot \alpha^{F}-X_{i}^{H}{ }^{H} \alpha^{H}\right)+\left(\phi^{F}-\psi^{H}\right) T_{i 0}+\left(v^{F}-v^{H}\right) \xi_{i}
$$

and the latter is the difference between (4a) and (4b), noting that $T_{i l}{ }^{H}$ and $T_{i l}{ }^{F}$ only differ in the location, but not in the length of period:

$$
w_{i 2}^{H, M}-w_{i 2}^{H, S}=\left(\phi^{H}-\psi^{H}\right) T_{i 1}+\gamma_{i}
$$

Accounting for differences in the length of the work stay abroad relative to the time span in which the returns from the investment can be enjoyed, by weights $a$ and (1-a) and denoting the cost of

\footnotetext{
${ }^{5}$ We disregard of permanent migration, implying that the below assertions hold conditional on negative net expected benefits from permanent emigration. This is e.g. the case if legal restrictions prevent permanent settlement and work abroad. We further disregard of uncertainty as concerns the future realisations of variables relevant to the decision to migrate.
} 
return migration by $C^{6}$, combining (5a) and (5b) and including an individual shift term $\eta$ results in the following decision rule for assuming a temporary work assignment abroad.

$$
\begin{aligned}
P\left(m_{i}=1\right) & =1 \text { if } \pi_{i}=a\left(w_{i 1}{ }^{F}-w_{i 1}^{H}\right)+(1-a)\left(w_{i 2}^{H, M}-w_{i 2}^{H, S}\right)-C_{i}+\eta_{i} \\
& =a\left[\left(X_{i}{ }^{F} \cdot \alpha^{F}-X_{i}^{H}{ }^{H} \alpha^{H}\right)+\left(\phi^{F}-\psi^{H}\right) T_{i 0}+\left(v^{F}-\nu^{H}\right) \xi_{i}\right]+(1-a)\left[\left(\phi^{H}-\psi^{H}\right) T_{i 1}+\gamma_{i}\right]-C_{i}+\eta_{i}>0,
\end{aligned}
$$

and $\quad P(m=1)=0$ if $\pi \leq 0$

The propensity to emigrate increases in the following observed characteristics: first, with sector-specific wage differentials in the host as against the source country. We can expect these to be positive in any pair of countries in the context of Eastern to Western emigration. Second, in the differential valuation of domestically acquired human capital abroad, that may be positive or negative depending on the profession. Third, with the valuation of foreign working experience as compared to experience from the same spell spent working at home, upon return. Finally, in the total cost of the temporary move abroad, $C_{i}$. The fact that typically only a small fraction of a country's population chooses to emigrate reflects high related costs, be it of monetary, psychic or social nature. ${ }^{7}$

The propensity to migrate is positively related to both the unobserved human capital component $\xi$ and the unobserved skill enhancement $\gamma_{i}$. One may also think of the shift term $\eta$ to be correlated with unobserved earnings determinants, if it includes an unobserved characteristic that enhances earnings capacities and lowers the individual cost of emigration at the same time. Ability is an example for such a characteristic. These terms render the propensity to emigrate $P(m)$ endogenous with respect to the earnings equation.

\subsection{Methodology}

Foreign working experience may offer the opportunity of skill upgrading to the migrant. Within the given regulatory constraints, participation in foreign working experience is based on a a voluntary decision, and it may result in a better labour market position upon return. With these features, a work stay abroad is comparable to an active labour market policy programme.

The policy evaluation literature has adopted interest in two types of effects on programme participation: the impact of the programme on an average (random) individual from a sample of both

\footnotetext{
${ }^{6}$ In the context of temporary migration, migration costs arise both with leaving the home country and with returning. Related monetary and psychic costs may arise with the search for a job, establishing and reestablishing professional and private networks, housing relocation, and the like.

${ }^{7}$ In the present inquiry we disregard of emigration. In the terms of (7), we can think of $C^{E}$ to be exorbitantly high for permanent settlement abroad. This assumption is realistic insofar as for the moment, most of the EU-15 countries have barred work immigration from the New Members.
} 
participants and non-participants, known as average treatment effect (ATE), and its impact on an average person from those who participate, known as the effect of the treatment to the treated $\left(\mathrm{ATE}_{1}\right.$, where the subscript denotes treatment). ${ }^{8}$ Formally, with the outcomes of interest such as earnings from work with and without treatment, $w_{1}$ and $w_{0}$ respectively, a participation index $m$ with values 1 or 0 , and an array of conditioning variables $X, \mathrm{ATE}=\mathrm{E}\left(w_{1}-w_{0} \mid X\right)$ and $\mathrm{ATE}_{1}=\left(w_{1}-w_{0} \mid X, m=1\right)$. The difference between the two effects is the person specific gain, i.e. the difference of the average individual stochastic term $\varepsilon$ with and without treatment, conditional on participation and a set of control variables. Formally, $\mathrm{ATE}-\mathrm{ATE}_{1}=E\left(\varepsilon_{l}-\varepsilon_{0} \mid X, m=1\right) .{ }^{9} \mathrm{ATE}$ and $\mathrm{ATE}_{1}$ will be equal only if programme participation and treatment outcomes are independent of each other. ${ }^{10}$ This is, however, not the case if people make their choice based on their net expected benefit, i.e. self select into participation. Self selection, be it based on observed or unobservable factors, results in different sizes of the impact on the treated and the total population respectively.

A difficulty in establishing both ATE and $\mathrm{ATE}_{1}$ is that components of both effects are counterfactuals: in the post programme period, one can either observe $w_{1}$ but not $w_{0}$ for the participants, or $w_{0}$ but not $w_{1}$ for the non-participants. Unless participation and outcomes are independent of each other, the estimation of these effects calls for specific techniques and identifying assumptions, depending on the type of selection. In particular, different estimators are suited to the analysis of selection on observables and unobservables respectively. ${ }^{11}$

Turning to our analysis of returning migrants' earnings, using the policy evaluation terminology, the effect of treatment of the treated, $\mathrm{ATE}_{1}$, is the wage premium to labour market experience to those who have been abroad, while ATE is the wage premium to a random individual from the full sample. The observed outcomes are the earnings $w_{2}^{H, M}=E\left(w_{1, t} \mid m=1\right)$ for movers, and $w_{2}^{H, S}=E\left(w_{0, t} \mid m=0\right)$ for the stayers in the post-programme period $t$. If temporary migration does respond to the net expected benefit as outlined in section 2.1, ATE and $\mathrm{ATE}_{1}$ will differ, and selectivity needs to be accounted for specifically.

In the evaluation framework, comparisons of treated and untreated individuals require some identifying assumption, i.e. a restriction on the differences between the two groups or before and after treatment outcomes respectively. Estimators available for cross-section datasets rely on the assumption that before treatment, outcomes for the treated and untreated are the same (conditional on observed characteristics), i.e. $E\left(w_{0} \mid X, m=0\right)=E\left(w_{0} \mid X, m=1\right)$. In our application, this identifying assumption rules

\footnotetext{
${ }^{8}$ For textbook discussions of the estimation of treatment effects, see Heckman, LaLonde and Smith 1999, and Wooldridge 2001: 603ff.

${ }^{9}$ See Wooldridge 2001: 607.

10 See ibid.: 605.

${ }^{11}$ See the methodology discussion of econometric evaluation estimators of Heckman et al. (1999: 1941ff.).
} 
out systematic differences between movers and stayers by unobserved human capital characteristics that exist before the move. This requires $v^{F}-v^{H}=0$ such that $\xi$ drops from the selection equation (8). ${ }^{12}$

If there are neither ex ante nor ex post differences between stayers' and movers' unobserved characteristics and no selection effects respectively, the premium to foreign working experience can be established as the mean difference of the two groups' earnings conditional on the other human capital characteristics. If selection is nonrandom however, the following two cases can be distinguished, each calling for a specific estimation methodology. First, selection can be based on observed earnings determinants. As an example, individuals with certain occupations may be more likely to opt for a work stay abroad, if these occupations offer higher differential returns abroad as compared to the home country. With such selection assumptions, $\mathrm{ATE}_{1}$ can be estimated with instrumental variable (IV) or matching methods. This framework allows for unobserved gains from participation, but such gains must not impact on the participation decision. In our case, this implies either $\gamma=0$ or $\gamma \neq 0$ but $\gamma$ not to be among the arguments of the index function $\pi$. In the second case, unobserved gains are available from the treatment, and they are anticipated in the decision to participate, as described by equation (6). In this case, $\mathrm{ATE}_{1}$ cannot be consistently estimated with IV because instruments for the individual's participation propensity will be correlated with the unobserved component of the posttreatment outcome. Instead, $\mathrm{ATE}_{1}$ can be obtained from earnings functions corrected for sample selection.

Our empirical analysis is placed in the most general framework that allows for unobserved gains from a work stay abroad to have an impact both on post return earnings and on the decision to move as well. In particular, we estimate an endogenous switching model, i.e. separate earnings functions for movers and stayers that include correction terms for selection into the respective regime. ${ }^{13}$ In addition, we account for selectivity into labour market activity. This is motivated by the fact that the majority of the individuals making part of our sample are not working, which is in most cases due to unfinished education. The selection equations are estimated by probit, considering three cases: first, two independent probit equations describing independent decisions, second, seemingly

${ }^{12}$ Note that, provided that this assumption is appropriate, our treatment effect estimates do not suffer from bias due to unobserved characteristics in the wage equation: such characteristics drop out of the index function $\pi$ so that movers and stayers respectively do not systematically differ on these lines, while the treatment effect, as a difference of treatment to no treatment earnings, is not affected anyway. Concerning the other components of the error term in the migration selection equation, expected unobserved gains from the move $\gamma$ are accounted for by our methodology applied, while unobserved characteristics $\eta$ do not play a role in the earnings function.

${ }^{13}$ An exemplary discussion and application of this methodology is provided in Heitmueller's (2004) analysis of the public-private sector wage gap in Scotland. Regarding returns to foreign work experience, this methodology is also applied by Co et al. (1999) and (among others) by de Coulon and Piracha (2003). 
unrelated probit accounting for unobserved individual characteristics that may impact on both the labour force participation and the migration decision in a similar way (such as the number of children on which we do not have information), and, third, bivariate probit that models the work and foreign experience status as two dimensions of the same decision process. We then include the selection correction terms for active work status and the respective mover/stayer status into earnings functions estimated separately for the movers and stayers by OLS, and apply a Hausman test to investigate the equality of the obtained results. In the separate probits, the nonselection hazards related to labour force participation $\lambda_{L l}$, to being a stayer $\lambda_{M 0}$, and being a mover $\lambda_{M l}$ respectively are calculated as follows (Heitmueller, 2004):

$$
\begin{aligned}
& \lambda_{i L I}=\phi\left(F_{i}{ }^{\prime} \mu\right) / \Phi\left(F_{i}{ }^{\prime} \mu\right) \\
& \lambda_{i M 0}=-\phi\left(G_{i}{ }^{\prime} \delta\right) /\left(1-\Phi\left(G_{i}{ }^{\prime} \delta\right)\right)
\end{aligned}
$$

and

$$
\lambda_{i M l}=\phi\left(G_{i}{ }^{\prime} \delta\right) / \Phi\left(G_{i}^{\prime} \delta\right)
$$

where $\phi$ and $\Phi$ denote the standard normal density and distribution functions, while $F_{i}$ and $G_{i}$ represent the vectors of covariates from the participation and mover/stayer probits, and $\mu$ and $\delta$ are the estimated coefficients from these functions respectively.

The seemingly unrelated and the bivariate probit specifications provide for specific correction terms for labour force participation for each of the two earnings equations, since the decisions to work and to move are jointly modelled. Denoting the bivariate standard distribution function with $\Phi_{2}$, with the correlation coefficient between the standard errors of the two equations $\rho$ and with $n=\left(1-\rho^{2}\right)^{-0.5}$, for the stayers' earnings equation, the two correction terms are

$$
\begin{aligned}
& \lambda_{i L 1,0}=\phi\left(F_{i}{ }^{\prime} \mu\right) \Phi\left[-n\left(G_{i}{ }^{\prime} \delta-\rho F_{i}{ }^{\prime} \mu\right)\right] / \Phi_{2}\left(-G_{i}{ }^{\prime} \delta, F_{i}{ }^{\prime} \delta,-\rho\right) \\
& \text { and } \\
& \lambda_{i M 0,1}=-\phi\left(G_{i}{ }^{\prime} \delta\right) \Phi\left[n\left(F_{i}^{\prime} \mu-\rho G_{i}{ }^{\prime} \delta\right)\right] / \Phi_{2}\left(-G_{i}{ }^{\prime} \delta, F_{i}{ }^{\prime} \mu,-\rho\right)
\end{aligned}
$$

while for the movers' earnings equation, these terms are

$$
\begin{aligned}
& \lambda_{i L l, l}=\phi\left(F_{i}{ }^{\prime} \mu\right) \Phi\left[n\left(G^{\prime} \delta-\rho F^{\prime} \mu\right)\right] / \Phi_{2}\left(G_{i}{ }^{\prime} \delta, F_{i}{ }^{\prime} \mu, \rho\right) \\
& \text { and } \\
& \lambda_{i M l, l}=\phi\left(G_{i}{ }^{\prime} \delta\right) \Phi\left[n\left(F_{i}{ }^{\prime} \mu-\rho G_{i}{ }^{\prime} \delta\right)\right] / \Phi_{2}\left(G_{i}{ }^{\prime} \delta, F_{i}{ }^{\prime} \mu, \rho\right)
\end{aligned}
$$

For comparison, we also present joint OLS estimates of stayers' and movers' wages including a dummy variable for the latter that provides the mean difference estimator of returns to foreign experience. Note however that this estimator is consistent and unbiased only if there are no systematic differences in stayers' and movers' characteristics, whether observed or unobserved. The variables included into the selection and earnings equations respectively are explained in the next section. 


\section{The data}

\subsection{Dataset and variables}

Our empirical research makes use of the 2003 spring wave of the Candidate Countries Eurobarometer (CCEB). This survey is a special draw of the CCEB that extends over citizens ${ }^{14}$ aged 15 to 24 . The CCEB and its EU member state counterpart, the Eurobarometer (EB) are regular surveys of public opinion on important topics of European citizenship released by the European Commission. They are typically conducted twice a year by national institutes of the EU member states and canditate countries respectively. ${ }^{15}$ Some collections cover special topics. Such a round was the 2003 spring CCEB where the situation of the youth was examined. EB data have been widely used for political economy topics. In the context of migration, Krieger (2004), for example, draws upon EB data to account for the migration potential from Eastern Europe, based on statements of the willingness to emigrate. This rich dataset enables novel analysis. In particular, a consistent set of source country socio-economic micro data including information on work related stays abroad and covering a broad range of host countries has to our knowledge not been used so far. The multiplicity of source and destination countries considered may offer a broader picture on the topic than the existing single country studies, especially since migration regimes tend to have strong country specific characteristics.

The Youth CCEB 2003 was collected in March and April 2003 in the ten EU applicant countries that became EU members in 2004 as well as in Romania, Bulgaria, and Turkey. On average, approx. 800 interviews were conducted in each of these countries, except for Cyprus and Malta with half as many interviewees, and Bulgaria, where around 1000 persons were interviewed. The total size of the cross-country sample is $9754 .{ }^{16}$ We restrict the analysis to the subsample of males, for women's labour market behaviour is likely to be governed by different patterns. In addition, a separate analysis of the subsample of females would be impeded by the low number of cases with active labour market status and foreign work related experience. ${ }^{17}$ The subsample of males includes 4876 individuals. From

${ }^{14}$ In Estonia, permanent residents were considered instead. Another irregularity refers to the case of Cyprus where only the Republic was covered.

${ }^{15}$ For the Eastern EU applicant countries, surveys called Eastern European Eurobarometer were conducted in 1992 to 1997. After a four-year break, the series was re-launched in 2000, under the new label Candidate Countries Eurobarometer.

16 The interviews were selected by a multi-stage random probability sampling procedure. The national surveys are representative with respect to NUTS 2 area coverage, region types, the distribution of population and nationalities respectively, and settlement types.

${ }^{17}$ The dataset offers 37 records of females with foreign work related experience that contain all variables needed. Tentative estimation results for females are available from the author upon request. 
these, we discard Turkey and an additional 565 cases due to missing data. The summary statistics and probit estimation results described in section 3.2 are based on a final sample containing information on 3831 individuals. From these, another 45 observations (three of which are of movers) are lost in the earnings regressions because of missing data on regressors.

We distinguish between working and nonworking individuals based on information on their basic activity and their main source of regular income. A person is considered working if he pursues a regular job, casual work, or black market activities. Related to income, the individuals were asked how much they personally get on average per month. Additionally, information is provided on the source of this income. We define income from work as income stemming from either of the above activities. Income is provided in euro (as well as in national currencies). A distinction between net and gross terms is unfortunately not made, but the lack of precision of the question suggests that net revenues are likely to be reported at least by employees. The measure, however, may be ambiguous for the self employed. Information on the hours worked per month is lacking so that we need to proxy wages with earnings. We can control for regular or part time work assignments however.

Our foreign work experience variable is positive if the individual has been in either of the 15 EU member states as of 2003, Switzerland, Liechtenstein, or Norway for work or business related reasons in the past two years. The data do not distinguish genuine work assignments abroad from occasional business trips. As our aim is to establish evidence on West to East transfer of human capital, we do not think that this broad definition poses a severe problem. We, however, also explored the magnitude of the divergence between a narrow and broad definition of the foreign work experience indicator. In the standard CCEB surveys of 2001 to 2003 where questions on the countries visited are put differently, around 3.3 per cent of the surveyed report to have worked in either of the above countries. ${ }^{18}$ In comparison, in our original dataset, 2.8 per cent report work or business related travels to these countries. Second, participation in business meetings, conferences, fairs and other professional encounters abroad will also offer ample opportunity to acquire new standards, meet new technologies, and adapt one's skills and comportment, and will thus also add to the transfer of knowledge from Western to Eastern Europe. ${ }^{19}$ Therefore, the ambiguity finally relates to the amount of time spent abroad, i.e. the length or frequency of the stays. The fact that our data only records travels and stays abroad in the two years prior to the survey is unlikely to sizeably blur the picture. If differential human capital acquired during a work stay abroad has not materialized in positive returns within two years upon return, it may rather depreciate than turn effective.

\footnotetext{
${ }^{18}$ Unfortunately, the standard CCEB data have shortcomings that impede their evaluation with regard to earnings premia to returning migrants.

${ }^{19}$ For simplicity, we refer to any of these cases as "return migration". The heterogeneity of the cases covered should be borne in mind.
} 
By the dependent variables of the two selection equations, our final sample is composed as follows: 2451 individuals i.e. 64 per cent are non-working, of which 50 persons ( 2 per cent) report work related stays abroad. From the working subsample of 1380 (36 per cent of total), 95 i.e. 7 per cent report such stays abroad. The considerably lower share of those with foreign working experience among the non working is not surprising given that the majority report to pursue their education.

In addition to work status, foreign work experience status, and income, our analysis makes use of information on the individual's personal status (single or couple), education level (where we distinguish three categories), potential work experience, occupation (either of four categories, or unspecified), the type of her settlement (three types), and her country of residence. Precise definitions of the variables are given in the appendix.

\subsection{Summary statistics}

Summary statistics of the data are provided in tables 1-3 (see the appendix). By the categories distinguished above, our sample has the following features: typically, against those who are not in the labour market, ${ }^{20}$ those working are older (21.2 years on average against 18.4 years), are more likely to live with a partner (in the two groups, 11 and 2 per cent report such a state respectively), have finished school a longer time ago (4.7 years against 3.8), are better educated (two thirds have finished secondary education, while two thirds of the non-working have only primary education finished), and have a slight tendency to be concentrated in large towns (31 against 29 per cent of the non-working, but also with weaker presence in smaller towns - 33 against 36 per cent of the non-working). These differences reflect that most of the non-working have not finished their education yet. There are also country differences in labour force participation: comparatively higher levels are typical of the Czech and the Slovak Republics, Hungary, Latvia, Malta, and Slovenia, while labour force participation is below average in in Bulgaria, Lithuania, and Poland.

More than 50 per cent of the working individuals with Western European work related experience are nationals of Estonia, Bulgaria, Latvia, and Hungary. Among the destination countries, most important are the large EU-15 member states - Germany, France, Italy, and the UK -, and neighbouring countries, such as Austria for Hungarians and Slovenians, Greece for Bulgarians, Finland for Estonians and Sweden for citizens of the Baltic countries. Part of the individuals with Western European working experience have been to several destination countries. ${ }^{21}$

\footnotetext{
${ }^{20}$ For the sake of simpler expression, we include the unemployed in this category as well.

${ }^{21}$ Note that the above figures do not give a fully accurate picture on the destination countries of foreign working experience, since we have included cases of that cover multiple stays in Western European countries
} 
Comparing those with foreign work related stays in the last two years with those who have not had such stays, the former are more likely to live with a partner, be better educated, and have finished school longer ago than the latter. They are on average 22.1 years old (stayers: 19.3 years) and have finished school 5.1 years ago (stayers: 4.1 years). Besides, 17 per cent live with a partner ( 5 per cent of the non movers), 75 per cent have secondary and 8 per cent have tertiary education (stayers: 46 and 3 per cent respectively). These differences between the two groups are parallel to those between the working and non-working: this suggests that the two state variables may describe outcomes of a joint decision. By type of settlement, there are no significant differences between the movers and stayers: roughly one third come from rural areas, small towns, and large towns respectively. Also, there are fewer country differences between these groups than in the case of labour force participation: movers are rather concentrated in Estonia and Lithuania, while there are less represented in in Cyprus and the Czech Republic.

Finally, looking at differences between movers and stayers conditional on labour force participation, the former earn substantially more than the latter: the average monthly work income of the movers amounts to 157 per cent of the stayers' earnings, 345 against 219 euro. ${ }^{22}$ Besides, the former are more likely to live with a partner (22 against 11 per cent), they are less frequently occupying part time jobs (33 against 47 per cent), and they possess a better education (73 per cent have secondary education and 8 per cent have tertiary education, against 65 and 5 per cent of the stayers respectively). Concerning their occupation, managers and self-employed are over represented among the movers: 10 and 8 per cent are in these occupations against 5 and 4 per cent of the stayers. We find no significant country specific differences between these two groups.

\section{$4 \quad$ Estimation results}

\subsection{Specifications of the estimating equations}

We assess potential earnings differentials of young Eastern Europeans with and without Western European work related experience in an endogenous switching regression framework, as explained in section 2.2. This model implies the estimation of a reduced form probit describing the propensity to go for such experience as a first step. From the results, correction terms for the nonselection hazard -

with different purposes. These cases unambiguously relate to Western European work related experience, but the data do not allow to match the purpose and the country of the stay.

${ }^{22}$ The income figures provided in table 3 may appear very low. Note however that these are averages of young people's earnings in transition countries, many of which hold part time jobs, and some of which are labour market entrants. 
inverse Mill's ratios - can be recovered. These are then used in the OLS estimation of separate earnings functions for stayers and movers respectively. In addition to selection into the mover/stayer status, we account for selection into the labour force. The high inactivity rate in our sample that relates to unfinished education suggests the presence of such a selection effect in particular. As for the specification of the selection probits, three cases are distinguished: first, two separate probit equations for labour force participation and foreign work experience respectively, second, seemingly unrelated probit equations, and, third, the modelling of the respective decisions as outcomes of a bivariate probit model. ${ }^{23}$ We then estimate the earnings equations in several versions distinguished by way sample selection is corrected for: a first pair of equations is estimated without selection parameters, a second is run with correction for labour force participation from the univariate probit regression. Three pairs of earnings regressions are then provided with correction terms for both work and mover/stayer status, that are calculated from the univariate probit, the seemingly unrelated probit, and the bivariate probit respectively. We present estimation results for the selection probit equations in table 6 and for the earnings equation in tables 7 (for stayers) and 8 (for movers). The latter also include the results of a Hausman test of the equality of the coefficients (we have excluded the country dummies and selection terms from the test). For comparison, OLS estimation results with a dummy variable for foreign working experience are shown in table 5. Stayers' and movers' earnings for the two groups respectively predicted from the specifications are, finally, reported in table 15.

As mentioned before, the sample is restricted to young males. All regressions contain dummies for the respective source country. Dummies for education levels and the type of settlement are used both for the selection and the earnings equations. The first are to reflect opportunity costs of foregone leisure, while both sets of dummies are to describe the availability of job opportunities both domestically and abroad. These effects should be relevant both for the selection and the earnings equations. Marital status ${ }^{24}$ is assumed to play a role in both participation decisions: we expect males living with a partner to face more family responsibility and to be therefore more likely to work. The expected effect of living with a spouse or partner on the willingness to go abroad is unclear, though: one could expect such males to pursue higher professional aspirations and take opportunities of training abroad, but such people may be expected to be less mobile than singles as well. Based on these considerations, we include a marital status dummy in both selection equations.

\footnotetext{
${ }^{23}$ Note that both the seemingly unrelated probit and the bivariate probit allow for nozero correlation of the error terms of the two probits estimated. In the case of the latter, the two probits are estimated with the same set of regressors, while in the former, one variable in each equation is excluded from the other. In our application, the seemingly unrelated probits are estimated with the same regressors as the independent probits, with the decisive difference that error correlation is accounted for.

${ }^{24}$ In our analysis we make no distinction between marriage and nonmarital cohabitation of couples.
} 
We further use potential working experience in the labour force participation equation: we expect the time passed since the finishing of education to matter for labour force participation and to capture difficulties of labour market entry in particular. In contrast, time passed since leaving school should not necessarily matter for taking the chance of a work related stay abroad: although labour market entry difficulties prevail in Western Europe as well, anecdotal evidence suggests that in these countries, there is a number of job training opportunities for young people without substantial work experience more or less easily available to foreigners, such as traineeships. Instead, we include age in the foreign working experience probit. Younger people should be more likely to participate in work related stays abroad, due to their lower cost of relocation. On the other hand, one may also expect a reverse effect that reflects increasing independence, given that the individuals in our sample are aged 24 and less. The inclusion of age among the regressors in the first probit but not in the second of potential experience in the latter but not in the first provides for the distinction between seemingly unrelated and bivariate probit. Note that a seemingly unrelated probit model of the two decisions with the same set of variables in both equations results in bivariate probit.

In addition to the education and settlement type related dummy variables as stated above, our earnings equations contain dummies for part-time work, activity in the black economy, and employment in the public sector. In addition, we control for four types of professions: manual and white collar worker, manager, and self employed person respectively. For a number of individuals reported to be working, there is no information on the occupation: "unspecified occupation" is our (presumably heterogenous) omitted category. Although no identification requirement prohibits the inclusion of a variable in both a selection equation and the earnings equation (because identification is provided for by functional form assumptions), we have not included potential experience in the reported earnings regressions because it proved insignificant.

Note that in our OLS regressions, we employ categorical explanatory variables in a semilogarithmic model. The relative change in the dependent variable in levels related to the factor represented by the dummy variable can be recovered as the exponential of the coefficient minus 1 (see Halvorsen and Palmquist, 1980). The discussion of our results is based on this transformation. In table 9, we present the transformed coefficients of the earnings functions for stayers and movers summarized in tables 7 and 8 .

The Central and Eastern Eurobarometer contains information on conversation level language skills of the interviewees. As an extension of our analysis, we have re-estimated the earnings functions with control variables for proficiency of any Western European language, distinguishing languages related to a visit in a respective country in the past two years, and languages of other Western European countries. Accounting for the knowledge of Western European languages allows investigating specifically whether employers' valuation of foreign work experience is driven by the linguistic proficiency of the potential employee, which may be acquired domestically to some extent 
as well. Among the language skills matched by a stay in a respective country, we cannot distinguish whether such skills were acquired during a work related or other type of stay. The acquisition of language skills may suffer from endogeneity with respect to the decision to participate in a stay abroad. We do not specifically address this potential source of bias. Results for the earnings functions with the same selection correction terms as used for the base model are given in tables 10 and 11 .

To investigate our interpretation that higher pay for individuals with Western European work related experience in the EU accession countries is due to the diffusion of skills practiced in the economies of the EEA of 2003 that facilitate the catching up and economic integration of the Eastern European economies with the former, we have re-run our estimation procedure with foreign work experience made in Eastern, instead of Western, European countries. Individuals who assume work abroad in Eastern Europe prove mobility and mental flexibility as well. However, we expect that the potential for knowledge diffusion among former members of the Council for Mutual Economic Assistance is substantially below the potentialities in the West to East European perspective. This analysis should exclude individuals with Western European working experience. Indeed, there are 23 such observations among those with and 70 among those without Eastern European work experience. However, excluding these leaves us with 46 observations with positive migration and labour force participation status, which has proven insufficient for strong results. Therefore, we provide estimation results for the earnings functions related to Eastern European working experience in tables 13 and 14 and the respective participation probits in table 12, based on data that contain individuals with Western European work related experience as well, which is however not specifically accounted for. The mean difference estimator of the earnings with and without Eastern European work related experience is summarized in column $\mathrm{C}$ of table 5 . We also provide the mean difference estimator of the earnings function on the subsample of which individuals with Western European work related experience are removed (table 5, column D).

In addition to the regressions reported in the appendix, we have run further specifications to check for the robustness of our findings. We do not report the respective results in detail. In qualitative terms, they do not alter the discussed findings. Among others, we have repeated the regressions leaving out the observations with primary education only. We have further applied country demeaned income, calculating separate means by country for movers and stayers respectively. Further, we have tried for the relevance of the individual's attitude towards foreigners in both the selection and the earnings equations: assuming that xenophobia is exogenous to foreign work related experience, one could well argue that more xenophobic individuals are less likely to head for a work stay in Western Europe, i.e. that they have higher related cost. Also, xenophobia could be motivated by fear from competition and thus reflect the individual's labour market position and unobserved ability respectively. We have not found, however, attitude towards foreigners to have explanatory power in either of our equations. 


\subsection{Estimation results: selection equations}

The results of the separate probit estimations and the seemingly unrelated probit are very similar. The error terms of the two choice equations are significantly but weakly correlated with each other, with a correlation coefficient of 0.15 . The bivariate probit estimation provides somewhat different results. Here, a correlation coefficient between the error terms of the choice equations of 0.1 is found. Both sets of results provide suggestive evidence of a common component in the error terms to impact on both the decision to work and to go abroad respectively. Based on the log likelihood statistic, the bivariate probit appears to be the most appropriate specification. The improvement of the statistic in comparison with the separate probits is, however, modest. While the bivariate probit is empirically more generous, the first two probit specifications are rather supported by a reasoned choice of regressors. We will discuss the results from the first two sets of probit regressions and the bivariate probit in turn.

The estimation results of the univarite probits on labour force participation include the following: first, young males living with a partner are more likely to work than singles. The effect is much stronger if the choices of work and mover/stayer status are assumed to be two separate decisions. Marital status has the strongest effect on labour force participation from the individual's personal characteristics: it increases the probability by 0.85 standard deviations. Comparing two individuals with average characteristics, the person having a spouse or partner is 33 percentage points more likely to be working than the person having no such relationship. We find working experience to influence the probability of labour force participation of young male Eastern Europeans as expected. This effect is not very strong, though. For an average individual, one more year of potential working experience increases the likelihood to work by 6 percentage points. Labour force participation increases in education levels. An average young man having only primary school education is 28 percentage points less likely to work than a similar man with secondary education, while tertiary education increases this probability by 10 percentage points. Compared with small towns, young males in rural areas are slightly more likely to be working. Everything else equal, the difference in the probability to work is 3 percentage points. We do not find systematic differences in labour force participation between small and large towns. Among the countries considered, some are found to have specifically particularly low labour force participation rates among the young males, in particular Cyprus, Latvia, Poland, and Romania.

Turning to the results on the probability to go for work related reasons abroad, our univariate probit regressions provide the following results. It is not the younger but the older young men who are more likely to go to Western Europe for professional reasons. One year more of age increases the respective probability in the case of a young man with otherwise average characteristics by 0.75 percentage points. This is not as low as it may appear, keeping in mind that the share of people with foreign work related experience in the sample is below 4 per cent. 
The better educated are more likely to participate in Western European work related stays. There are no significant differences between those with secondary and tertiary level education, but those lacking such degrees are significantly less likely to go abroad. From the first probit equation, we find that having no secondary or better education reduces the probability of an average individual to go abroad by 1.3 percentage points. The seemingly unrelated probit regression provides a somewhat stronger effect. The propensity to go for work abroad is not found to vary by type of settlement. Across countries, higher probabilities are predicted in particular for Lithanian, Maltese and Polish young men as well as, in the case of the seemingly unrelated probit, for Estonians.

The results for the bivariate probit are different from those discussed above in the following respects. Looking first at labour force participation, as of marriage or cohabitation, a considerably weaker but still highly significant effect is estimated. While experience is significant only quadratically, we find that the likelihood of labour force participation is strongly increasing in age. Note that age is not among the regressors in the other two probit equations on labour force participation. Another important difference against the results discussed previously is that people are found less likely to work if they possess tertiary level education. The results for the migration probit do not differ substantially from those discussed for the univariate specifications discussed above.

In table 12, we also provide the selection equations for Eastern European foreign work experience. The differences found for the probability of labour force participation from the seemingly unrelated and bivariate probit are negligible as compared to the base model with Western European experience. Noteworthy differences in the probability of foreign work related stays in Eastern as compared to Western Europe are, first, that we do not find education levels to matter for the latter. Second, as compared to individuals from Poland, foreign work experience in other Eastern European countries is significantly higher among Latvians, Lithuanians and Slovaks - as well as among Romanians according to the bilateral probit estimation results - and lower in Cyprus, while similar country characteristics are not found for Western European work related experience. The higher propensity of Eastern European work experience abroad among the nationals of the aforementioned countries certainly relates to the ethnic minorities in these countries (Russians in the Baltic countries, Hungarians in Romania and Slovakia). Finally, the estimations for Eastern European work abroad show stronger correlation in the error terms of the equations for labour force participation and foreign work experience.

\subsection{Earnings of stayers and movers}

Our model described in section 2.1 formulates differential returns to foreign work experience to materialise in the coefficient to the dummy variable indicating such experience. Empirically, one may allow for interactions of this dummy with other determinants of the earnings function, to account for 
the possibility that foreign working experience is mediated by the individual's other characteristics. The endogenous switching model allows for this possibility in the most generous way, for different earnings functions are estimated for stayers and movers. Our empirical application does in fact yield different earnings equations for stayers and movers. Below, we describe these in turn. The earnings premia expressed as ratios as compared to the case characterised by the omitted dummies are summarized in table 9.

According to our estimation results for stayers, those occupying part-time jobs earn 26 to 28 per cent less than those working full time. Unrecorded economic activity yields a premium of around 23 per cent. In the specification without corrections for selection, we find a premium of 9 per cent for activities in the public sector. This result is however not confirmed by the selectivity corrected specifications. Compared to those with secondary level education, those lacking such a degree earn substantially less, while those having higher education obtain considerably more. The different specifications yield somewhat different coefficients. The curtailment to be accepted by the least educated is highest in the equation without correction, amounting to 44 per cent as compared to those with secondary education. The other equations produce coefficients that imply a reduction of 22 or 30 per cent. Similarly, the returns to occupations are different across specifications. There is however a consistent order of such returns as compared to the observations where an occupation has not been specified: manual and white collar workers obtain differential returns that are comparable in size, but lower than those of the other professional groups considered. The returns to self employment are estimated to be highest, in particular higher than those obtained by holders of managerial positions. For the self employed, we find earnings premia as compared to the omitted category of unspecified occupation that are 10 to 60 percentage points higher than for manual workers. In the case of the self employed, one may suspect that earnings have been overstated in the survey. The differences between managers' and manual workers' earnings appear rather low - in fact, the specification with selection correction terms from the bivariate probit estimation yields lower returns to the former than to the latter-, but they may be explained by the short professional careers of the individuals, especially those in positions requiring higher education. In addition, these results may also reflect that young Eastern Europeans tend to be found in leading positions of young firms or not for profit organisations that cannot offer overly high rewards for their activity. While people living in rural areas are not found to incur lower pay as compared to those in small towns, young males living in large cities earn 17 to 27 per cent more than the former, depending on the specification. The country dummies reflect common sense about the income levels of the countries surveyed: Earnings are highest in Cyprus, Malta, Slovenia, and Hungary, and lowest in Bulgaria and Romania. Average salaries of Cypriots are around three to four times higher than of Polish nationals.

A decisive feature of our methodology is the consideration of selection effects. In this regard, our specifications provide ambiguous results. We find a negative coefficient for the non-selection hazard relating to labour force participation in all specifications of stayers' earnings (see table 7). The 
coefficient to the inverse Mill's ratio is the standard deviation of the error term times the correlation coefficient of the error terms between the selection and the earnings regression: its sign allows reading off the type of selection. It can thus be seen that in our sample, is those with less favourable earnings capabilities rather choose to work. This result is intuitive for that many of the non working in our sample are pursuing their education. Looking at the decision to stay, results are sensitive to the specification of the probit equations from which the non-selection hazards are obtained. The significant error correlation of the two probit equations supports specification (4) or (5) in table 7. The correction terms as described in equation (10b) account for non-selection into non-migration: a positive coefficient implies negative correlation between the error terms relating to the propensity to stay, and to stayers' earnings. Hence, specification (4) suggests that those who are rather likely to stay receive lower stayers' earnings than a random individual from the sample.

As of the movers, part time workers earn 36 per cent less than those occupying full time jobs. Other than for stayers, we do not find a premium for either black market activities or employment in the public sector. All specifications reveal a strong negative impact of lacking secondary or higher education on earnings of 40 to 50 per cent. The predicted coefficients are higher in the specifications that do not account for selection into the mover status. Similarly, these specifications predict an earnings premium for those who hold a tertiary level degree of 50 per cent, a result that is not confirmed once selection into foreign work experience is controlled for. On the ordering of returns to the four occupations distinguished, the specifications bear similar results: The self employed are predicted to earn most, more than twice as much as those from the "unspecified" category, followed by the white collar workers, who obtain 90 to 100 per cent more. Managers and manual workers are predicted to obtain earnings that are by around 60 per cent and 44 per cent higher respectively, but this latter result is again insignificant in the specifications controlling for selection in foreign experience. Interestingly, the regressions with correction terms from the probits with error correlation predict that young males with foreign experience living in rural areas earn 35 per cent more than those located in small towns. For large towns, no such effect is found. Young people from Malta are found to have highest earnings, while lowest income prevails in Bulgaria and Romania. The country dummy for the Czech Republic is also, consistently across specifications, around one standard deviation below the average of all countries. Finally, no specification does provide significant selection correction terms for either labour force participation or work related stay in Western Europe. Apparently, those individuals who have chosen this experience do just as good upon return than any random individual.

From comparing the earnings equations for movers and stayers respectively, the following insights emerge. Part time working stayers are less unfavourably paid than part time working movers, compared to their full time working counterparts. Certainly, this may be due to differences in the average hours worked in these two groups. On the other hand, the results may reflect situations where better jobs that are specifically targeted at those with foreign experience demand full time presence, while temporary jobs chosen by the migrants do not offer possibilities to make use of the specific 
skills acquired abroad. As of the returns to black market activities, the estimated premium for stayers of around 25 per cent appears reasonable, thinking of respective jobs as probably not the most prestigious and well paid, and considering saved deductions for taxes and social security contributions. The insignificant coefficients in the movers' equation may reflect that the pay in formal jobs for those with work related foreign experience outperforms the black market pay of similar individuals enough to counterbalance the tax advantage of the latter, assuming that specific qualities acquired abroad are more likely to be demanded and rewarded in formal labour markets. Looking at education levels, the estimated difference in pay between those with and without a secondary degree is considerably higher for movers. On the other hand, additional rewards for a tertiary degree are robustly found for stayers but not for movers. This can be seen as evidence suggesting that professions requiring only primary education do not offer much opportunity for the acquisition of such skills abroad that are valuable in domestic labour markets. Besides, higher education is not rewarded per se among the movers: this may reflect that among the movers, careers with higher salaries are also available to those with secondary education only. It could also be the case that earnings premia for foreign working experience becomes effective later in the careers of the highly educated, bearing in mind that such individuals in our sample must be at the beginning of their professional development. Finally, while stayers obtain higher earnings in large cities, among the movers it is, in contrast, those in rural areas who obtain additional rewards. Since movers' proven international mobility may translate into domestic mobility as well, this finding may reflect the differential compensation that movers with specific qualities expect to receive in such areas in order to stay there.

We have checked for the equality of the coefficients except those for the country dummies, the selection correction terms and the constant in the stayers' and movers' equation by the means of a Hausman test. The results are reported in the bottom rows of table 8 . Based on this test, the equality of the earnings premia related to the human capital and job characteristics that we tested for can be rejected in all specifications but the one with the selection correction terms obtained from the bivariate probit equations.

The earnings equations for stayers and movers with control variables for EU language skills are presented in tables 10 and 11 respectively. The additional control variables leave most results qualitatively unchanged, including the results of the Hausman test on the equality of the main coefficients in the two equations. From the language dummies, we find that stayers obtain an earnings premium of 22 to 32 per cent for language skills that relate to destination countries of recent visits, whereas there is no significant premium to proficiency in other Western European languages. For the movers, we do not find a premium for proficiency in either type of language. ${ }^{25}$ I.e., the knowledge of

\footnotetext{
${ }^{25}$ Note that there is variation in the "EU language, visited" variable among the movers as well: part of the individuals have reported a work related stay in a Western European country but have not indicated
} 
Western European countries' languages is indeed an asset in Eastern Europe, but according to our results, it is not these skills specifically for which individuals with Western European working experience are better paid. This finding is also supported by the results of the mean difference estimator presented in column B of table 5 that similarly shows a premium for Western European of around 22 per cent. ${ }^{26}$ As a further difference against the estimations without the language dummies, no specification reveals a premium for tertiary education for the movers, and the curtailment for lacking secondary education is not robust across specifications either.

Looking at foreign work related experience acquired in Eastern European countries, the stayers' equation is broadly similar to the equation estimated for the non-movers to Western Europe: indeed, most of the observations are identical, and the selection correction terms do not change much. For the movers, we obtain fewer significant coefficients. In particular, we do not find a penalty for the lack of secondary education in all specifications, and no specification yields a premium for tertiary education. Interestingly, among those with Eastern work related experience abroad, we find positive selection into an active work status in most specifications. Most important however, the Hausman test does not allow to reject the equality of the tested coefficients. Finally, while the mean difference estimator still shows a premium to Eastern European work related experience, the significance of the respective coefficient vanishes once we exclude the observations with Western European experience from the sample (table 5, colums $\mathrm{C}$ and $\mathrm{D}$ ). We interpret these results as indicative evidence that it is indeed the superior skills acquired in the more advanced economies or cultural knowledge to facilitate the economic ties with these economies that is valuated by employers in Eastern Europe, and not just proven flexibility.

Earnings predicted from the different specifications, both of the stayers' and the movers' equation, are presented in table 8 by these two categories (in euro). All specifications predict higher earnings for movers by around 70 to 75 euro (depending on specification) or around one third of an average young stayer's salary, both if they choose to move as they did and if they had not decided to do so. Besides, on average, participating in a work related stay abroad results in better salaries both for the de facto movers and the stayers of a similarly 30 per cent. These findings allow to conclude the following: first, those who go abroad are equipped with considerably better earnings capabilities than those who do not. This is consistent with the finding of a negative truncation effect in the earnings equation of the stayers. Second, in the present comparative static framework, a returnee from a

conversation level proficiency of the language of the respective country. Part of these individuals are likely to have performed unskilled labour without specific linguistic requirements, while others may have worked in an international environment or may have reported travels to business gatherings that required the knowledge of English or French instead of the official language of the destination country.

${ }^{26}$ The estimation results without language dummies presented in column B imply an earnings premium of 29 per cent for those with Western European working experience. 
Western European work related stay from either of the factual movers' or stayers' group can expect a higher salary with this experience. We interpret this as evidence for the transfer of specific skills acquired in the West to the Eastern European economies. We do not find, however, evidence of differences in the extent of the premium to foreign a foreign work stay.

\section{Conclusion}

In the present study, we have investigated earnings differences between young males from Central and Eastern Europe with and without Western European work related experience respectively, using the Central and Eastern Youth Eurobameter dataset of spring 2003 in an endogenous switching regression framework that generously allows for differences in the earnings functions of the two groups considered as well as for the consideration of selection into such experience, be it on observables or unobservables. We have found a premium to Western European work experience of around one third of a stayer's earnings. In addition, our estimations highlighted specific differences in the rewards for various human capital characteristics of stayers and movers respectively. Among others, the less educated of the movers fare significantly worse than of the stayers, compared with the better educated in the respective group. Our findings further include evidence that among the individuals surveyed, the decisions to work and to go abroad respectively have at least a common (unobserved) determining factor or are taken simultaneously. Our results provide inconclusive evidence of selection in going abroad to work or not: while stayers are found to have worse stayers' earnings than movers, our estimations are unable to reveal significant differences in movers' earnings of both groups or in the gains from moving between the two groups, and selection effects are not found significant in the movers' earnings equation.

Irrespective of the existence of such effects, the increased earnings capability of those with Western European work related experience in Central European labour markets is evident and stable across specifications. Since potential endogeneity of selection is taken into account as far as the data permit, we can safely interpret this as evidence of substantial skills transmission from Western to Eastern Europe via international labour mobility. Further research is needed however to elaborate on this result. In particular, remaining ambiguities in our findings on selection effects and predicted earnings differentials need to be looked at.

Our analysis shows that temporary work migration is beneficial to the source country economies. However, it contains somewhat worrying implications as well. In particular, we find that the propensity to participate in Western European work related experience is comparatively lower among those with low education levels. With the result of substantial earnings premia to such experience, temporary migration appears to improve the labour market situation of those who are in a relatively advantageous position already, instead of providing a way out of poor conditions for the 
most disadvantaged. Speculating a bit, we may conclude that temporary migration adds to earnings inequality.

Our findings suggest that return migration that has become possible after the fall of the Iron Curtain is providing a mechanism to foster the catching up of the Eastern European economies. From a policy perspective, our results support the call for the extension of opportunities for temporary work migration to the Western economies, e.g. by exchange programmes or training schemes, in order to enhance such positive effects. In a longer term perspective, this is rather relevant for the countries of the Western Balkans, since all old EU members will have to grant free labour mobility to the citizens of the accession countries seven years after their EU entry at latest. On the other hand, the Eastern European source countries can similarly adopt appropriate measures to foster the return of their nationals working abroad who would otherwise become permanent emigrés. This will be even more important when the restrictions to labour mobility within the enlarged EU expire. Although first experiences with labour mobility in the enlarged EU do not yet allow to investigate the conditions under which East to West European labour migration is temporary or permanent, experiences with the Southern European enlargement are positive: allowing for unrestricted labour mobility has in fact encouraged return migration to the source countries in the Mediterranean. One can optimistically speculate that with free labour mobility in the enlarged EU, increased temporary moves will further contribute to the catching up of the Eastern European economies and the spread of more advanced techniques and standards.

Certainly, a limitation to the insights to be drawn from our study is the angle of partial equilibrium analysis. However, return migration from Central and Eastern to Western Europe is unlikely to take such dimensions that would put partial equilibrium results into question, even after the full introduction of EU-wide labour mobility. 


\section{References}

Bobeva, Daniela, and Jean-Pierre Garson, 2004, "Overview of bilateral agreements and other forms of labour recruitment", in Organisation for Economic Co-operation and Development, ed., Migration for employment: Bilateral agreements at a crossroads, Paris: OECD, p. 11-29.

Barrett, Alan, and Philip J. O'Connell, 2001, "Is there a wage premium for returning Irish migrants?", The Economic and Social Review 32(1), p. 1-21.

Borjas, George, and Bernt Bratsberg, 1996, "Who leaves? The out-migration of the foreign-born", The review of economics and statistics 78(1), 165-176.

Co, CatherineY., Ira N. Gang, and Myeong-Su Yun, 1999, "Returns to returning", mimeo.

Constant, Amelie, and Douglas S. Massey, 2002, "Return migration by German guestworkers: Neoclassical versus new economic theories", International Migration 40 (4), p. 5-38.

de Coulon, Augustin, and Matloob Piracha, 2003, "Self-selection and the performance of return migrants: The source country perspective", Centre for Economic Performance Discussion Papers, London.

Dustmann, Christian, and Oliver Kirchkamp, 2002, "The optimal migration duration and activity choice after re-migration", mimeo.

Halvorsen, Robert, and Raymond Palmquist, 1980, "The interpretation of dummy variables in semilogarithmic equations", American Economic Review 70 (3), p. 474-475.

Hárs, Ágnes, 2003, "Channeled East-West labour migration in the frame of bilateral agreements", Budapest Working Paper on the Labour Market no. 2003/1, Budapest.

Heckman, James J., Robert L. Lalonde, and Jeffrey A. Smith, 1999, “The economics and econometrics of active labour market programmes", in Orley Ashenfelter and David Card, eds., Handbook of Labor Economics 3, 1865-2095.

Heitmueller, Axel, 2004, "Public-private sector wage differentials in Scotland: An endogenous switching model”, IZA Discussion Paper no. 992, Bonn.

International Organization for Migration, 2005, Word migration 2005: Costs and benefits of international migration, Geneva.

Kaczmarczyk, Pawel, and Marek Okólski, 2005, "International migration in Central and Eastern Europe - Current and future trends", United Nationals expert group meeting on international migration and development, mimeo. 
Krieger, Hubert, 2004, "Migration trends in an enlarged Europe", European Foundation for the Improvement of Living and Working Conditions series on quality of life in Europe, Luxembourg: Office for Official Publications of the European Communities.

OECD, 2004, "Migration for employment: Bilateral agreements at a crossroads", Paris.

OECD, 1998, "Report on the temporary employment of foreigners in several OECD counries", in ibid., ed., "Trends in international migration: Continuous reporting system on migration", Part III, Sopemi Annual Report, Paris.

Roy, A. D., 1951, "Some thoughts on the distribution of earnings", Oxford Economic Papers 3 (2), 135-146.

Smith, Jeffrey, 2000, "A critical survey of empirical methods for evaluating active labor market policies”, Schweizerische Zeitschrift für Volkswirtschaft und Statistik 136 (3), 1-22.

Wooldridge, Jeffrey, 2002, Econometric analysis of cross section and panel data, Cambridge, Mass.: The MIT Press. 


\section{Appendix}

\section{Description of variables}

Income: The CCEB contains information on the individual's regular monthly income (in Euro) as well as its source. Our income variable uses the income level contained in the survey if the main source is a regular job, casual work, or some black market activity. If information on the main source is missing but the individual's occupation suggests regular work (i.e. either of the following categories: manual worker, white collar worker, manager, self employed - while the categories left out of consideration include unemployed, houseperson, student, retired, and other). In the regression analyses, we employ the logarithm of the income variable.

Couple: The CCEB distinguishes between the following marital and personal status of the individuals respectively: married, living as married, single, divorced, separated, and widowed. We assign value 1 to a dummy variable related to individuals living with their partner in case of either of the first two categories, and 0 otherwise.

Experience: The CCEB contains the number of years passed since the individual has finished education. We use these figures to describe potential work experience.

Education levels: The CCEB offers detailed information on the individual's education level that is adjusted to national education systems and degrees. We summarize these education levels to three categories: primary education (i.e. elementary school), secondary education (up to completed high school), and tertiary education (completed postsecondary education). Information on education levels is captured by dummy variables. In the regression analyses, secondary education is the omitted category.

Part time employment: In the occupations category, the CCEB makes a distinction between full time and part time or occasional work. Our part time employment dummy reflects the latter two with value one.

Black economy activity: The CCEB has asked for the main source of the individual's income. Our black economy dummy is positive if the individual has indicated black economy activities.

Public employment: The CCEB contains information on whether the individual has received his pay from a public authority. This is reflected by our public employment dummy with value one.

Settlement: In the survey, three types of settlement are distinguished: Rural area, small town, and large town. We make use of these categories.

Country: The CCEB contains information on the country of residence of the individual. We create dummies to distinguish the twelve EU accession countries (as of 2003). Of these countries, only citizens were surveyed.

EU language: The individuals participating in the CCEB survey were asked about their conversation level proficiency of a list of languages. Among these, we distinguish the official languages of those EU-15 countries which the respective interviewee has visited for any reason in the past two years, and of those where no such visit has taken place. 
Table 1

Data summary, by work status

\begin{tabular}{|l|rc|rc|c|}
\hline Variable & \multicolumn{2}{|c|}{ (a) $\mathbf{L}=\mathbf{0}$} & \multicolumn{2}{c|}{ (b) L=1 } & (b) - (a) \\
& \multicolumn{1}{|c|}{ mean } & st.dev. & \multicolumn{1}{c|}{ mean } & st.dev. & mean diff. \\
\hline age & 18.4435 & $(0.0516)$ & 21.1681 & $(0.0693)$ & $2.7246^{* * *}$ \\
couple & 0.0257 & $(0.1583)$ & 0.1181 & $(0.3229)$ & $0.0924^{* * *}$ \\
experience & 3.8095 & $(2.3213)$ & 4.7101 & $(2.4513)$ & $0.9006^{* * *}$ \\
education: primary & 0.6116 & $(0.4875)$ & 0.2993 & $(0.4581)$ & $-0.3123^{* * *}$ \\
education: secondary & 0.3688 & $(0.4826)$ & 0.6486 & $(0.4776)$ & $0.2798^{* * *}$ \\
education: tertiary & 0.0196 & $(0.1386)$ & 0.0522 & $(0.2225)$ & $0.0326^{* * *}$ \\
settlement: rural & 0.3431 & $(0.4748)$ & 0.3543 & $(0.4785)$ & $0.0112^{* *}$ \\
settlement: small town & 0.3635 & $(0.4811)$ & 0.3304 & $(0.4705)$ & $-0.0331^{* *}$ \\
settlement: large town & 0.2933 & $(0.4554)$ & 0.3152 & $(0.4648)$ & $0.0219^{*}$ \\
Bulgaria & 0.1346 & $(0.3414)$ & 0.113 & $(0.3168)$ & $-0.0216^{* *}$ \\
Cyprus & 0.0477 & $(0.2132)$ & 0.0406 & $(0.1974)$ & -0.0071 \\
Czech R. & 0.0506 & $(0.2192)$ & 0.063 & $(0.2431)$ & $0.0124^{*}$ \\
Estonia & 0.0996 & $(0.2995)$ & 0.0928 & $(0.2902)$ & -0.0068 \\
Hungary & 0.093 & $(0.2905)$ & 0.1109 & $(0.3141)$ & $0.0179^{*}$ \\
Latvia & 0.0812 & $(0.2732)$ & 0.1101 & $(0.3132)$ & $0.0289^{* * *}$ \\
Lithuania & 0.1155 & $(0.3196)$ & 0.0717 & $(0.2581)$ & $-0.0438^{* * *}$ \\
Malta & 0.0363 & $(0.1871)$ & 0.0565 & $(0.2310)$ & $0.0202^{* * *}$ \\
Poland & 0.1134 & $(0.3172)$ & 0.0543 & $(0.2268)$ & $-0.0591^{* * *}$ \\
Romania & 0.0661 & $(0.2485)$ & 0.0717 & $(0.2581)$ & 0.0056 \\
Slovakia & 0.0849 & $(0.2787)$ & 0.1058 & $(0.3077)$ & $0.0209^{* *}$ \\
Slovenia & 0.0771 & $(0.2668)$ & 0.1094 & $(0.3123)$ & $0.0323^{* * *}$ \\
\hline observations & 2451 & \multicolumn{2}{|c|}{1380} & \\
\hline
\end{tabular}

$* * *, * *, *$ denote significance at $1 \%, 5 \%, 10 \%$ resp. (one-sided test of equal means).
Table 2

Data summary, by migration status

\begin{tabular}{|c|c|c|c|c|c|}
\hline \multirow[t]{2}{*}{ Variable } & \multicolumn{2}{|c|}{ (a) $\mathbf{M = 0}$} & \multicolumn{2}{|c|}{ (b) $M=1$} & \multirow{2}{*}{$\begin{array}{c}\text { (b) - (a) } \\
\text { mean diff. }\end{array}$} \\
\hline & mean & st.dev. & mean & st.dev. & \\
\hline age & 19.3196 & $(0.0469)$ & 22.1035 & $(0.1833)$ & 2.7839 \\
\hline couple & 0.0545 & $(0.2271)$ & 0.1724 & $(0.3790)$ & $0.1179^{* * *}$ \\
\hline experience & 4.0966 & (2.3935) & 5.0828 & (2.5780) & $0.9862^{* * *}$ \\
\hline education: primary & 0.5117 & $(0.4999)$ & 0.1793 & $(0.3849)$ & $-0.3324^{* * *}$ \\
\hline education: secondary & 0.4588 & $(0.4984)$ & 0.7448 & $(0.4375)$ & $0.2860^{* * *}$ \\
\hline education: tertiary & 0.0296 & $(0.1694)$ & 0.0759 & $(0.2657)$ & $0.0463^{* * *}$ \\
\hline settlement: rural & 0.3481 & $(0.4764)$ & 0.3241 & $(0.4697)$ & -0.0240 \\
\hline settlement: small town & 0.3513 & $(0.4775)$ & 0.3586 & $(0.4813)$ & 0.0073 \\
\hline settlement: large town & 0.3006 & $(0.4586)$ & 0.3172 & $(0.4670)$ & 0.0166 \\
\hline Bulgaria & 0.1272 & $(0.3333)$ & 0.1172 & $(0.3228)$ & -0.0100 \\
\hline Cyprus & 0.0461 & (0.2098) & 0.0207 & $(0.1428)$ & $-0.0254^{*}$ \\
\hline Czech R. & 0.0564 & $(0.2308)$ & 0.0207 & $(0.1428)$ & $-0.0357^{* *}$ \\
\hline Estonia & 0.0941 & $(0.2921)$ & 0.1724 & $(0.3790)$ & $0.0783^{* * *}$ \\
\hline Hungary & 0.1001 & $(0.3002)$ & 0.0828 & $(0.2765)$ & -0.0173 \\
\hline Latvia & 0.0928 & $(0.2902)$ & 0.0621 & $(0.2421)$ & -0.0307 \\
\hline Lithuania & 0.0982 & $(0.2976)$ & 0.1379 & $(0.3460)$ & $0.0397^{*}$ \\
\hline Malta & 0.0431 & $(0.2032)$ & 0.0552 & $(0.2291)$ & 0.0121 \\
\hline Poland & 0.0922 & $(0.2894)$ & 0.0897 & $(0.2867)$ & -0.0025 \\
\hline Romania & 0.0686 & $(0.2529)$ & 0.0552 & $(0.2291)$ & -0.0134 \\
\hline Slovakia & 0.0928 & $(0.2902)$ & 0.0828 & $(0.2765)$ & -0.0100 \\
\hline Slovenia & 0.0882 & $(0.2836)$ & 0.1034 & $(0.3056)$ & 0.0152 \\
\hline observations & 36 & & 14 & & \\
\hline
\end{tabular}

$* * *, * *, *$ denote significance at $1 \%, 5 \%, 10 \%$ resp. (one-sided test of equal means). 
Table 3

Data summary, by migration status, working subsample

\begin{tabular}{|c|c|c|c|c|c|}
\hline \multirow[t]{2}{*}{ Variable } & \multicolumn{2}{|c|}{ (a) $\mathrm{L}=1, \mathrm{M}=\mathbf{0}$} & \multicolumn{2}{|c|}{ (b) $\mathrm{L}=1, \mathrm{M}=1$} & \multirow{2}{*}{$\begin{array}{l}\text { (b) - (a) } \\
\text { mean diff. }\end{array}$} \\
\hline & mean & st.dev. & mean & st.dev. & \\
\hline income, $€$ & 219.14 & $(256.91)$ & 345.41 & $(331.19)$ & $126.27^{* * *}$ \\
\hline couple & 0.1127 & $(0.3164)$ & 0.2151 & $(0.4131)$ & $0.1024^{* * *}$ \\
\hline experience & 4.6916 & (2.4699) & 4.8065 & $(2.2470)$ & 0.1149 \\
\hline education: primary & 0.3035 & $(0.4600)$ & 0.1828 & $(0.3886)$ & $-0.1207^{* * *}$ \\
\hline education: secondary & 0.6457 & $(0.4785)$ & 0.7312 & $(0.4457)$ & $0.0855^{* *}$ \\
\hline education: tertiary & 0.0507 & $(0.2195)$ & 0.0860 & $(0.2819)$ & $0.0353^{*}$ \\
\hline temporary job & 0.4726 & $(0.4995)$ & 0.3333 & $(0.4740)$ & $-0.1393^{* * *}$ \\
\hline black market activity & 0.0717 & $(0.2580)$ & 0.0860 & $(0.2819)$ & 0.0143 \\
\hline public employer & 0.2456 & $(0.4306)$ & 0.1828 & $(0.3886)$ & -0.0628 \\
\hline occupation: manual & 0.3398 & $(0.4738)$ & 0.3871 & $(0.4897)$ & 0.0473 \\
\hline occupation: white collar & 0.0950 & $(0.2933)$ & 0.1290 & $(0.3371)$ & 0.0340 \\
\hline occupation: manager & 0.0523 & $(0.2228)$ & 0.1075 & $(0.3115)$ & $0.0552^{* *}$ \\
\hline occupation: self employed & 0.0378 & $(0.1909)$ & 0.0860 & $(0.2819)$ & $0.0482^{* *}$ \\
\hline occupation: unspecified & 0.4750 & $(0.4996)$ & 0.2903 & $(0.4564)$ & -0.1847 \\
\hline settlement: rural & 0.3583 & $(0.4797)$ & 0.3548 & $(0.4811)$ & -0.0035 \\
\hline settlement: small town & 0.3285 & $(0.4699)$ & 0.3226 & $(0.4700)$ & -0.0059 \\
\hline settlement: large town & 0.3132 & $(0.4640)$ & 0.3226 & $(0.4700)$ & 0.0094 \\
\hline Bulgaria & 0.1119 & $(0.3154)$ & 0.1398 & $(0.3486)$ & 0.0279 \\
\hline Cyprus & 0.0427 & $(0.2022)$ & 0.0323 & $(0.1776)$ & -0.0104 \\
\hline Czech R. & 0.0676 & $(0.2512)$ & 0.0215 & $(0.1458)$ & -0.0461 \\
\hline Estonia & 0.0886 & $(0.2842)$ & 0.1828 & $(0.3886)$ & 0.0942 \\
\hline Hungary & 0.1151 & $(0.3193)$ & 0.0968 & $(0.2973)$ & -0.0183 \\
\hline Latvia & 0.1103 & $(0.3134)$ & 0.0753 & $(0.2653)$ & -0.0350 \\
\hline Lithuania & 0.0628 & $(0.2427)$ & 0.1075 & $(0.3115)$ & 0.0447 \\
\hline Malta & 0.0572 & $(0.2323)$ & 0.0753 & $(0.2653)$ & 0.0181 \\
\hline Poland & 0.0539 & $(0.2260)$ & 0.0645 & $(0.2470)$ & 0.0106 \\
\hline Romania & 0.0692 & $(0.2540)$ & 0.0430 & $(0.2040)$ & -0.0262 \\
\hline Slovakia & 0.1071 & $(0.3093)$ & 0.0753 & $(0.2653)$ & -0.0318 \\
\hline Slovenia & 0.1135 & $(0.3174)$ & 0.0860 & $(0.2819)$ & -0.0275 \\
\hline observations & & & & & \\
\hline
\end{tabular}

$* * *, * * * *$ denote significance at $1 \%, 5 \%, 10 \%$ resp. (one-sided test of equal means).
Table 4 Visits to Western Europe: Source and destination countries

From/to:
\begin{tabular}{|l|cccccccccccccccccccccc|c|}
\hline & BE & DK & GE & GR & ES & FR & IE & IT & LU & NL & AT & PT & SF & SE & UK & CH & LI & NW & SUM \\
\hline BG & 2 & 0 & 4 & 5 & 0 & 0 & 0 & 1 & 0 & 0 & 1 & 0 & 0 & 0 & 2 & 0 & 0 & 0 & 13 \\
CY & 0 & 1 & 0 & 3 & 0 & 1 & 0 & 2 & 0 & 2 & 0 & 0 & 0 & 1 & 1 & 0 & 0 & 0 & 3 \\
CZ & 0 & 0 & 2 & 0 & 0 & 1 & 0 & 1 & 0 & 2 & 0 & 0 & 0 & 1 & 1 & 1 & 0 & 0 & 2 \\
EE & 1 & 3 & 6 & 0 & 0 & 1 & 0 & 0 & 1 & 2 & 0 & 0 & 13 & 4 & 0 & 0 & 0 & 0 & 17 \\
HU & 1 & 1 & 6 & 1 & 1 & 1 & 1 & 2 & 1 & 2 & 8 & 1 & 0 & 0 & 1 & 2 & 0 & 0 & 9 \\
LV & 1 & 1 & 4 & 0 & 1 & 1 & 2 & 0 & 0 & 2 & 0 & 1 & 2 & 2 & 1 & 0 & 0 & 2 & 7 \\
LT & 1 & 1 & 5 & 0 & 0 & 2 & 0 & 1 & 0 & 1 & 1 & 0 & 0 & 3 & 1 & 0 & 0 & 0 & 10 \\
MT & 2 & 1 & 2 & 1 & 2 & 2 & 1 & 5 & 2 & 2 & 1 & 1 & 2 & 1 & 2 & 1 & 0 & 1 & 7 \\
PL & 0 & 1 & 5 & 0 & 1 & 1 & 0 & 3 & 0 & 1 & 0 & 0 & 0 & 1 & 0 & 0 & 0 & 0 & 6 \\
RO & 0 & 0 & 2 & 0 & 0 & 0 & 0 & 1 & 0 & 0 & 0 & 0 & 0 & 0 & 0 & 1 & 0 & 0 & 4 \\
SK & 0 & 0 & 5 & 0 & 0 & 1 & 0 & 1 & 0 & 0 & 5 & 0 & 0 & 0 & 1 & 0 & 0 & 0 & 7 \\
SI & 1 & 0 & 3 & 0 & 1 & 2 & 0 & 4 & 0 & 1 & 6 & 0 & 0 & 0 & 1 & 1 & 0 & 0 & 8 \\
\hline SUM & 9 & 9 & 44 & 10 & 6 & 13 & 4 & 21 & 4 & 15 & 22 & 3 & 17 & 13 & 11 & 6 & 0 & 3 & 93 \\
\hline
\end{tabular}


Table 5 OLS estimation results: stayers' and movers' earnings, mean difference estimator

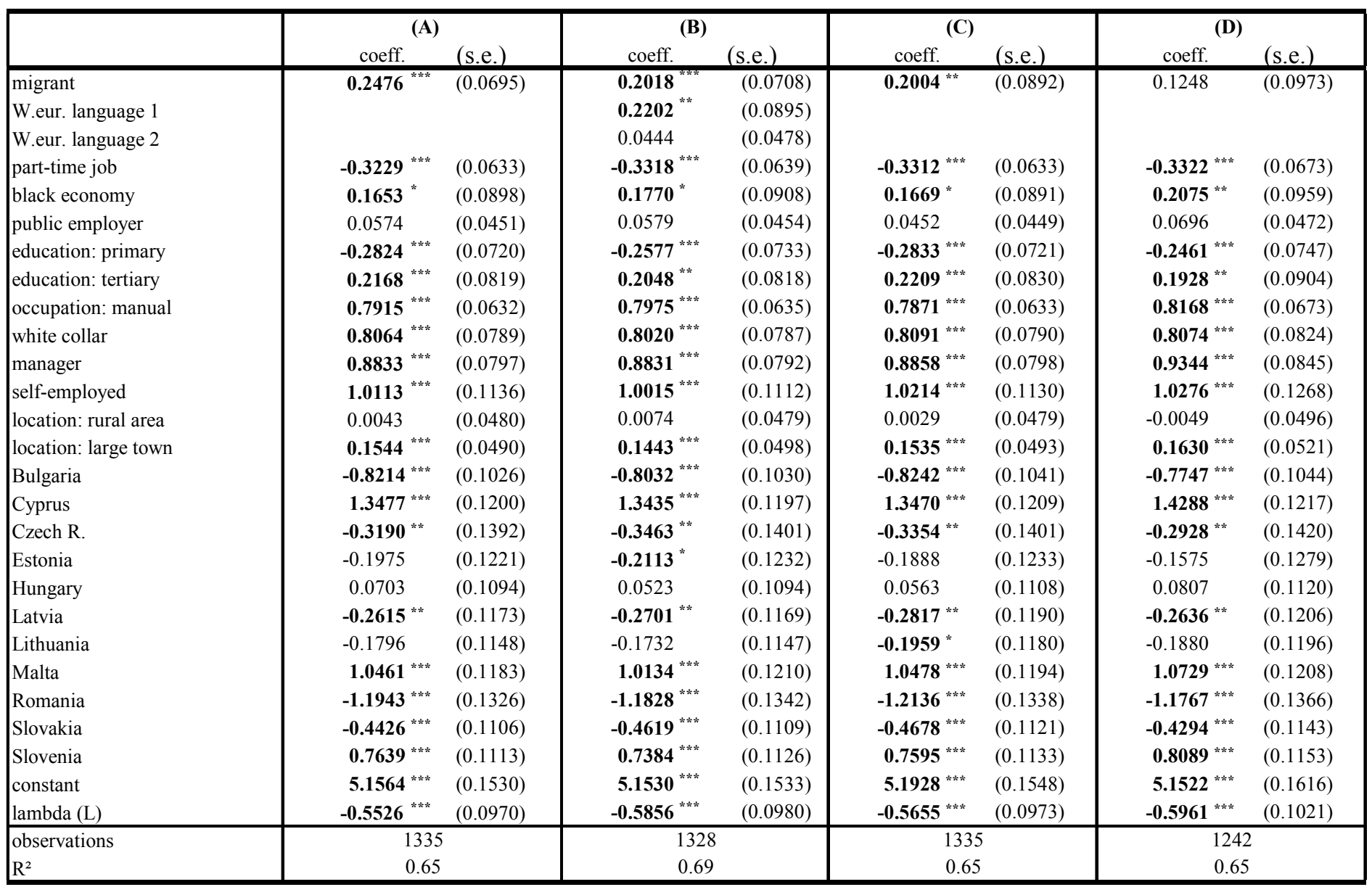

Specifications: (A) Western European working experience; (B) Western European working experience, language skills considered; (C) Eastern European working experience; (D) Eastern European working experience, Western experience dropped. $* * *, * *, *$ denote significance at $1 \%, 5 \%, 10 \%$ resp. Robust standard errors in parentheses. All explana-tory variables are binary. Omitted categories: no foreign work experience, full time job, emploment in formal economy, employer in private sector, completed secondary education, occupation unspecified, contry: Poland 
Table 6

Probit estimation results: selection equations

\begin{tabular}{|c|c|c|c|c|c|c|c|c|c|c|c|c|}
\hline \multirow{3}{*}{$\begin{array}{l}\text { Dependent variables: } \\
\text { working; Western Eur. work } \\
\text { experience }\end{array}$} & \multicolumn{4}{|c|}{ Separate probit estimations } & \multicolumn{4}{|c|}{ Seemingly unrelated probit } & \multicolumn{4}{|c|}{ Bivariate probit } \\
\hline & \multicolumn{2}{|c|}{$\mathbf{P}(\mathbf{l}=\mathbf{1})$} & \multicolumn{2}{|c|}{$\mathbf{P}(\mathbf{m}=1)$} & \multicolumn{2}{|c|}{$\mathbf{P}(\mathbf{l}=1)$} & \multicolumn{2}{|c|}{$P(m=1)$} & \multicolumn{2}{|c|}{$\mathbf{P}(\mathbf{l}=1)$} & \multicolumn{2}{|c|}{$\mathbf{P}(\mathbf{m}=1)$} \\
\hline & coeff. & (s.e.) & coeff. & (s.e.) & coeff. & (s.e.) & coeff. & (s.e.) & coeff. & (s.e.) & coeff. & (s.e.) \\
\hline couple & $0.8506^{* * * *}$ & $(0.0973)$ & 0.1585 & $(0.1285)$ & $0.8495^{* * * *}$ & $(0.0973)$ & 0.1958 & $(0.1292)$ & 0.3850 **** & $\overline{(0.1050)}$ & 0.1345 & $(0.1291)$ \\
\hline age & & & $0.1470^{* * * *}$ & $(0.0198)$ & & & 0.1310 *** & $(0.0212)$ & $0.3327^{* * * *}$ & $(0.0155)$ & $0.1809^{\text {*** }}$ & $(0.0230)$ \\
\hline experience & $0.1808^{* * *}$ & $(0.0343)$ & & & $0.1796^{* * *}$ & $(0.0344)$ & & & -0.0111 & $(0.0370)$ & -0.0223 & $(0.0648)$ \\
\hline experience squared & $-0.0143^{\text {**** }}$ & $(0.0033)$ & & & $-0.0142^{* * *}$ & $(0.0033)$ & & & $-0.0149^{* * *}$ & $(0.0034)$ & -0.0026 & $(0.0058)$ \\
\hline education: primary & $-0.78066^{* * *}$ & $(0.0514)$ & $-0.2626^{* *}$ & $(0.1149)$ & $-\mathbf{0 . 7 8 0 2} 2^{* * *}$ & $(0.0514)$ & $-0.3234^{* * *}$ & $(0.1158)$ & 0.0336 & $(0.0632)$ & -0.2080 * & $(0.1181)$ \\
\hline education: tertiary & 0.2660 ** & $(0.1298)$ & -0.1004 & $(0.1763)$ & $0.2654^{* *}$ & $(0.1299)$ & -0.0768 & $(0.1762)$ & $-0.3917^{\text {*** }}$ & $(0.1492)$ & -0.2078 & $(0.1874)$ \\
\hline settlement: rural & 0.0924 * & $(0.0529)$ & -0.0416 & $(0.0967)$ & 0.0919 * & $(0.0529)$ & -0.0359 & $(0.0968)$ & 0.0480 & $(0.0560)$ & -0.0389 & $(0.0967)$ \\
\hline settlement: large town & 0.0825 & $(0.0561)$ & -0.1177 & $(0.1006)$ & 0.0818 & $(0.0561)$ & -0.1102 & $(0.1007)$ & 0.0954 & $(0.0592)$ & -0.0922 & $(0.1010)$ \\
\hline Bulgaria & $0.3542^{* * * *}$ & $(0.1037)$ & -0.0918 & $(0.1763)$ & $0.3527^{* * *}$ & $(0.1036)$ & -0.0902 & $(0.1761)$ & $0.3069^{* * *}$ & $(0.1119)$ & -0.0927 & $(0.1758)$ \\
\hline Cyprus & 0.1124 & $(0.1331)$ & -0.3085 & $(0.2861)$ & 0.1110 & $(0.1331)$ & -0.3717 & $(0.2844)$ & $0.7447^{* * *}$ & $(0.1422)$ & -0.2941 & $(0.2871)$ \\
\hline Czech Republic & $0.8506^{* * *}$ & $(0.1205)$ & -0.2722 & $(0.2886)$ & $0.8487^{\text {**** }}$ & $(0.1204)$ & -0.2739 & $(0.2882)$ & $0.9927^{* * *}$ & $(0.1321)$ & -0.2731 & $(0.2895)$ \\
\hline Estonia & $0.5187^{* * *}$ & $(0.1094)$ & 0.4005 ** & $(0.1735)$ & $0.5190^{* * * *}$ & $(0.1093)$ & $0.3959^{* *}$ & $(0.1737)$ & $0.7030 * * *$ & $(0.1161)$ & 0.4231 ** & $(0.1742)$ \\
\hline Hungary & $0.6264^{* * * *}$ & $(0.1066)$ & -0.1149 & $(0.1924)$ & $0.6243^{* * * *}$ & $(0.1065)$ & -0.1160 & $(0.1921)$ & $0.6991^{* * *}$ & $(0.1144)$ & -0.0980 & $(0.1931)$ \\
\hline Latvia & $0.6675^{* * *}$ & $(0.1087)$ & -0.2030 & $(0.2025)$ & $0.6668^{* * * *}$ & $(0.1086)$ & -0.2121 & $(0.2027)$ & $0.8639^{* * *}$ & $(0.1141)$ & -0.1806 & $(0.2040)$ \\
\hline Lithuania & 0.153 & $(0.1111)$ & 0.1670 & $(0.1792)$ & 0.1517 & $(0.1110)$ & 0.1623 & $(0.1797)$ & $0.2088 *$ & $(0.1205)$ & 0.1782 & $(0.1796)$ \\
\hline Malta & $0.6653^{* * *}$ & $(0.1393)$ & 0.1491 & $(0.2289)$ & $0.6645^{* * * *}$ & $(0.1393)$ & 0.1324 & $(0.2268)$ & $0.9788^{* * * *}$ & $(0.1363)$ & 0.1706 & $(0.2287)$ \\
\hline Romania & 0.1416 & $(0.1176)$ & -0.2731 & $(0.2146)$ & 0.1394 & $(0.1175)$ & -0.2829 & $(0.2140)$ & $0.5592^{* * *}$ & $(0.1322)$ & -0.2147 & $(0.2141)$ \\
\hline Slovakia & $0.6282^{* * *}$ & $(0.1073)$ & -0.1079 & $(0.1952)$ & $0.6264^{* * * *}$ & $(0.1071)$ & -0.1023 & $(0.1949)$ & $0.7213^{* * * *}$ & $(0.1169)$ & -0.0930 & $(0.1963)$ \\
\hline Slovenia & $0.6241^{* * * *}$ & $(0.1102)$ & $-0.0955^{\text {**** }}$ & $(0.1897)$ & $0.6207^{\text {**** }}$ & $(0.1101)$ & -0.0777 & $(0.1889)$ & $0.8280^{* * * *}$ & $(0.1172)$ & 0.0035 & $(0.1913)$ \\
\hline constant & $-0.9897^{\text {**** }}$ & $(0.1194)$ & $-4.6634^{* * * *}$ & $(0.4652)$ & $-0.9871^{* * *}$ & $(0.1192)$ & $-4.3277^{* * * *}$ & $(0.4929)$ & $-7.1742^{* * * *}$ & $(0.3179)$ & $-5.2314^{* * *}$ & $(0.5230)$ \\
\hline observations & \multicolumn{2}{|c|}{3831} & \multicolumn{2}{|c|}{3831} & \multicolumn{4}{|c|}{3831} & \multicolumn{4}{|c|}{3831} \\
\hline log likelihood & \multicolumn{2}{|c|}{-2197.07} & \multicolumn{2}{|c|}{-533.90} & \multirow{2}{*}{\multicolumn{4}{|c|}{-2727.27}} & \multicolumn{4}{|c|}{-2455.35} \\
\hline rho & \multicolumn{2}{|c|}{--} & \multicolumn{2}{|c|}{-- } & & & & & \multicolumn{4}{|c|}{$0.1091^{*}$} \\
\hline
\end{tabular}

***, **, * denote significance at $1 \%, 5 \%, 10 \%$. Robust standard errors in parentheses. All variables except age, experience and experience squared are binary. Omitted categories are: Completed secondary education, single, living in small town, country: Poland. 
Table 7 OLS estimation results: stayers' earnings, various selection correction terms

\begin{tabular}{|c|c|c|c|c|c|c|c|c|c|c|}
\hline \multirow{2}{*}{$\begin{array}{l}\text { Dependent variable: } \\
\log \text { income, } €\end{array}$} & \multicolumn{2}{|c|}{ (1) } & \multicolumn{2}{|c|}{ (2) } & \multicolumn{2}{|c|}{ (3) } & \multicolumn{2}{|c|}{ (4) } & \multicolumn{2}{|c|}{ (5) } \\
\hline & coeff. & (s.e.) & coeff. & (s.e.) & coeff. & (s.e.) & coeff. & (s.e.) & coeff. & (s.e.) \\
\hline part-time job & $-0.3220^{* * * *}$ & $(0.0680)$ & $-0.3277^{* * *}$ & $(0.0671)$ & $-0.3040 *$ & $(0.0670)$ & $-0.3055^{* * *}$ & $(0.0672)$ & -0.3000 *** & $(0.0642)$ \\
\hline black economy & $0.2070 * *$ & $(0.0971)$ & $0.2099^{* *}$ & $(0.0962)$ & $0.2034^{* *}$ & $(0.0938)$ & 0.2036 ** & $(0.0941)$ & 0.2200 ** & $(0.0914)$ \\
\hline public employer & $0.0881 *$ & $(0.0470)$ & 0.0735 & $(0.0472)$ & 0.0725 & $(0.0469)$ & 0.0726 & $(0.0469)$ & 0.0650 & $(0.0454)$ \\
\hline education: primary & $-0.5744^{* * *}$ & $(0.0530)$ & $-0.2473^{* * *}$ & $(0.0748)$ & -0.2608 *** & $(0.0744)$ & -0.2539 *** & $(0.0744)$ & -0.3535 *** & $(0.0556)$ \\
\hline education: tertiary & $0.2624^{* * * *}$ & $(0.0880)$ & $0.1946^{* *}$ & $(0.0900)$ & $0.2015^{* *}$ & $(0.0908)$ & 0.1961 ** & $(0.0910)$ & $0.2400 * *$ & $(0.0966)$ \\
\hline occupation: manual & $0.8535^{* * * *}$ & $(0.0674)$ & 0.8205 *** & $(0.0672)$ & $0.7783^{* * *}$ & $(0.0664)$ & 0.7823 ***; & $(0.0665)$ & $0.5666^{* * * *}$ & $(0.0725)$ \\
\hline occupation: white collar & $0.8456{ }^{* * * *}$ & $(0.0832)$ & $0.8070 * *$ & $(0.0825)$ & 0.7403 *** & $(0.0830)$ & 0.7481 *** & $(0.0829)$ & $0.5097^{* * * *}$ & $(0.0905)$ \\
\hline occupation: manager & $0.9534^{* * * *}$ & $(0.0832)$ & $0.9346^{* * *}$ & $(0.0843)$ & $0.8161^{* * *}$ & $(0.0849)$ & $0.8214 *$ & $(0.0850)$ & $0.6232^{* * * *}$ & $(0.0910)$ \\
\hline occupation: self employed & $1.0862^{* * * *}$ & $(0.1333)$ & $1.0334 * *$ & $(0.1267)$ & $0.9494^{* *}$ & $(0.1293)$ & $0.9575^{* * *}$ & $(0.1290)$ & $0.7455^{* * * *}$ & $(0.1280)$ \\
\hline settlement: rural & 0.0220 & $(0.0499)$ & -0.0096 & $(0.0498)$ & 0.0387 & $(0.0502)$ & 0.0389 & $(0.0504)$ & -0.0063 & $(0.0488)$ \\
\hline settlement: large town & $0.1906^{* * * *}$ & $(0.0520)$ & $0.1607^{* * *}$ & $(0.0520)$ & $0.2387^{* *}$ & $(0.0539)$ & $0.2374^{* * *}$ & $(0.0541)$ & $0.1577^{* * *}$ & $(0.0524)$ \\
\hline Bulgaria & $-0.6144^{* * * *}$ & $(0.1064)$ & $-0.7769^{* * * 1}$ & $(0.1047)$ & -0.6450 *** & $(0.1046)$ & -0.6150 ***; & $(0.1052)$ & $-0.7677^{* * * *}$ & $(0.1075)$ \\
\hline Cyprus & $1.4514^{* * * *}$ & $(0.1252)$ & $1.4222^{* * *}$ & $(0.1218)$ & $1.6199^{* * *}$ & $(0.1227)$ & $1.6898^{* * *}$ & $(0.1254)$ & $1.2599^{* * *}$ & $(0.1411)$ \\
\hline Czech R. & 0.0358 & $(0.1364)$ & $-0.2853^{* *}$ & $(0.1416)$ & 0.0330 & $(0.1523)$ & 0.0972 & $(0.1552)$ & $-0.3447^{* *}$ & $(0.1562)$ \\
\hline Estonia & 0.0489 & $(0.1265)$ & -0.1563 & $(0.1278)$ & -0.1808 & $(0.1260)$ & -0.1829 & $(0.1255)$ & -0.1058 & $(0.1251)$ \\
\hline Hungary & $0.3240 * * * *$ & $(0.1104)$ & 0.0848 & $(0.1120)$ & $\mathbf{0 . 3 0 7 7}$ *** & $(0.1176)$ & $0.3540 * *$ & $(0.1194)$ & 0.0605 & $(0.1200)$ \\
\hline Latvia & 0.0154 & $(0.1166)$ & -0.2536 ** & $(0.1202)$ & 0.0186 & $(0.1279)$ & 0.0767 & $(0.1305)$ & -0.3336 ** & $(0.1378)$ \\
\hline Lithuania & -0.0929 & $(0.1201)$ & -0.1816 & $(0.1191)$ & $-0.2103^{*}$ & $(0.1178)$ & $-0.2135^{*}$ & $(0.1176)$ & -0.1077 & $(0.1196)$ \\
\hline Malta & $1.3018^{* * *}$ & (0.1194) & $1.0645^{* * *}$ & $(0.1210)$ & $1.2235^{* * *}$ & (0.1179) & $1.2622^{* * *}$ & (0.1184) & $1.0177^{* * *}$ & $(0.1172)$ \\
\hline Romania & $-1.0996^{* * *}$ & $(0.1411)$ & $-1.1622^{* * *}$ & $(0.1370)$ & -0.9630 ** & $(0.1381)$ & $-0.9167^{* *}$ & $(0.1395)$ & $-1.2255^{* * * *}$ & $(0.1443)$ \\
\hline Slovakia & -0.1761 & $(0.1118)$ & -0.4119 ** & $(0.1138)$ & $-0.1976 *$ & $(0.1178)$ & -0.1522 & $(0.1193)$ & $-0.4397^{* * * *}$ & $(0.1211)$ \\
\hline Slovenia & $1.0493^{* * *}$ & $(0.1146)$ & $0.8170 * *$ & $(0.1148)$ & $0.9942^{* * *}$ & $(0.1170)$ & $1.0264^{* * *}$ & $(0.1177)$ & $0.7352^{* * * *}$ & $(0.1225)$ \\
\hline constant & $4.4615^{\text {*** }}$ & $(0.1185)$ & $5.1407^{* * *}$ & $(0.1610)$ & $4.3727^{* * *}$ & $(0.2160)$ & $4.2623^{* * *}$ & $(0.2214)$ & $5.5051^{* * * *}$ & $(0.2544)$ \\
\hline lambda - L=1 & & & $-0.5949^{* * *}$ & $(0.1027)$ & $-0.2281 *$ & $(0.1262)$ & $-0.2224 *$ & $(0.1222)$ & & \\
\hline lambda $-\mathrm{M}=0$ & & & & & -2.1721 *** & $(0.3947)$ & 2.3352 *** & $(0.3916)$ & & \\
\hline lambda 1 - $\mathrm{L}=1, \mathrm{M}=0$ & & & & & & & & & -0.7729 **** & $(0.1201)$ \\
\hline lambda 2 - $\mathrm{L}=1, \mathrm{M}=0$ & & & & & & & & & -0.7056 & $(0.5428)$ \\
\hline observations & 124 & & 12 & & $\overline{12}$ & & $\overline{12}$ & & 124 & \\
\hline $\mathrm{R}^{2}$ & 0.6 & & 0.6 & & 0.6 & & 0. & & 0.6 & \\
\hline
\end{tabular}

$* * *, * * *$ denote significance at $1 \%, 5 \%, 10 \%$ respectively. Robust standard errors in parentheses. All explanatory variables are binary. Omitted categories are: full-time job, formal employment, employer in private sector, completed secondary education, occupation unspecified, living in small town, country: Poland. 


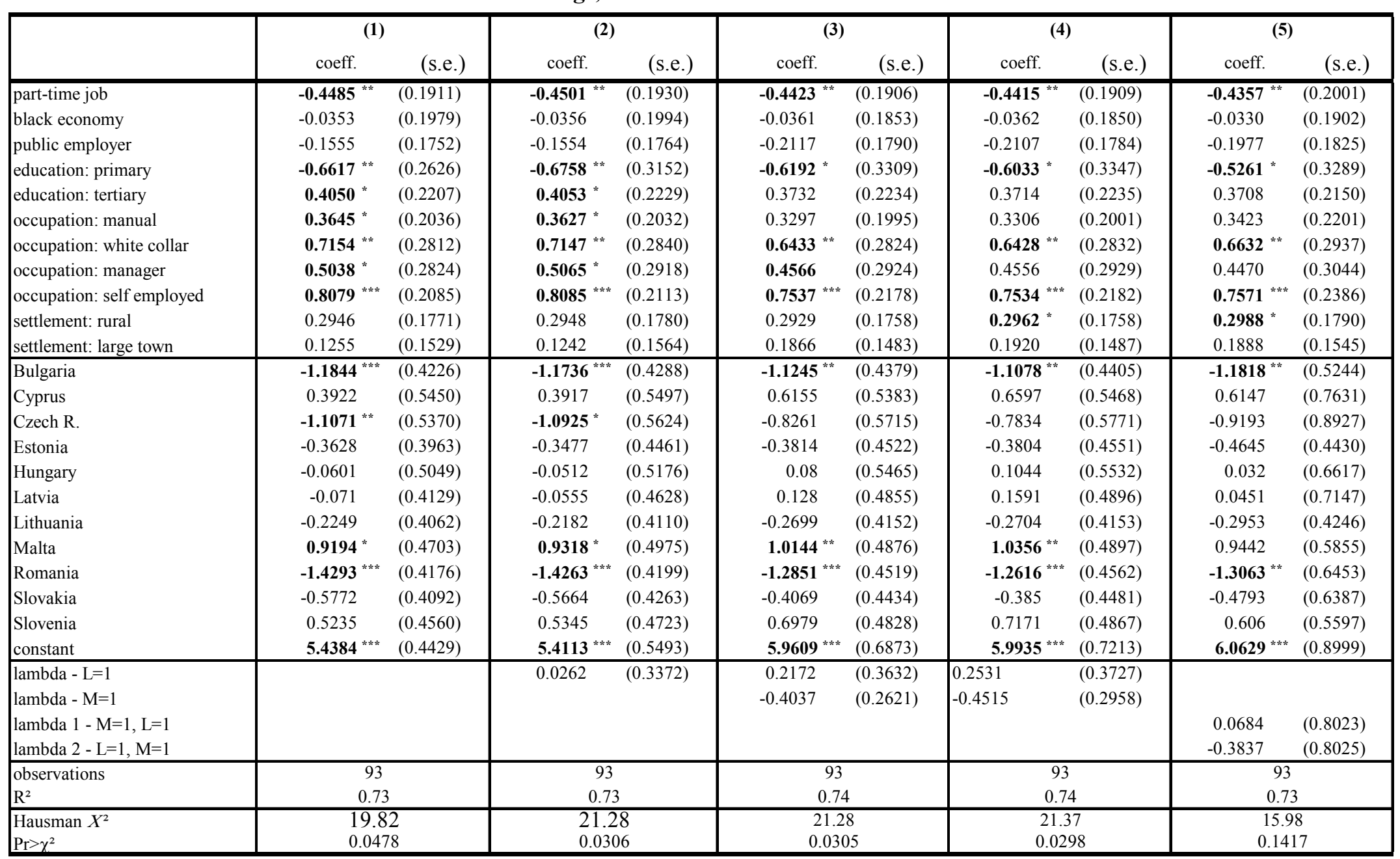

$* * *, * *, *$ denote significance at $1 \%, 5 \%, 10 \%$ respectively. Robust standard errors in parentheses. All explanatory variables are binary. Omitted categories are: full-time job, formal employment, employer in private sector, completed secondary education, occupation unspecified, living in small town, country: Poland. Hausman test - $\mathrm{H}_{0}$ : The difference between the coefficients of the stayers' and the movers' equation is not systematic (country dummies, the constant, and selection correction terms not included). 


\begin{tabular}{|c|c|c|c|c|c|c|c|c|c|c|}
\hline & (1) & (2) & (3) & (4) & (5) & (1) & (2) & (3) & (4) & (5) \\
\hline & \multicolumn{5}{|c|}{ stayers } & \multicolumn{5}{|c|}{ movers } \\
\hline part-time job & -0.28 & -0.28 & -0.26 & -0.26 & -0.26 & -0.36 & -0.36 & -0.36 & -0.36 & -0.35 \\
\hline black economy & 0.23 & 0.23 & 0.23 & 0.23 & 0.25 & -0.03 & -0.03 & -0.04 & -0.04 & -0.03 \\
\hline public employer & 0.09 & 0.08 & 0.08 & 0.08 & 0.07 & -0.14 & -0.14 & -0.19 & -0.19 & -0.18 \\
\hline education: primary & -0.44 & -0.22 & -0.23 & -0.22 & -0.30 & -0.48 & -0.49 & -0.46 & -0.45 & -0.41 \\
\hline education: tertiary & 0.30 & 0.21 & 0.22 & 0.22 & 0.27 & 0.50 & 0.50 & 0.45 & 0.45 & 0.45 \\
\hline occupation: manual & 1.35 & 1.27 & 1.18 & 1.19 & 0.76 & 0.44 & 0.44 & 0.39 & 0.39 & 0.41 \\
\hline occupation: white collar & 1.33 & 1.24 & 1.10 & 1.11 & 0.66 & 1.05 & 1.04 & 0.90 & 0.90 & 0.94 \\
\hline occupation: manager & 1.59 & 1.55 & 1.26 & 1.27 & 0.86 & 0.65 & 0.66 & 0.58 & 0.58 & 0.56 \\
\hline occupation: self employed & 1.96 & 1.81 & 1.58 & 1.61 & 1.11 & 1.24 & 1.24 & 1.12 & 1.12 & 1.13 \\
\hline settlement: rural & 0.02 & -0.01 & 0.04 & 0.04 & -0.01 & 0.34 & 0.34 & 0.34 & 0.34 & 0.35 \\
\hline settlement: large town & 0.21 & 0.17 & 0.27 & 0.27 & 0.17 & 0.13 & 0.13 & 0.21 & 0.21 & 0.21 \\
\hline Bulgaria & -0.46 & -0.54 & \begin{tabular}{c|c|}
-0.48 \\
\end{tabular} & -0.46 & -0.54 & -0.69 & -0.69 & $\begin{array}{l}-0.68 \\
\end{array}$ & -0.67 & -0.69 \\
\hline Cyprus & 3.27 & 3.15 & 4.05 & 4.42 & 2.53 & 0.48 & 0.48 & 0.85 & 0.93 & 0.85 \\
\hline Czech R. & 0.04 & -0.25 & 0.03 & 0.10 & -0.29 & -0.67 & -0.66 & -0.56 & -0.54 & -0.60 \\
\hline Estonia & 0.05 & -0.14 & -0.17 & -0.17 & -0.10 & -0.30 & -0.29 & -0.32 & -0.32 & -0.37 \\
\hline Hungary & 0.38 & 0.09 & 0.36 & 0.42 & 0.06 & -0.06 & -0.05 & 0.08 & 0.11 & 0.03 \\
\hline Latvia & 0.02 & -0.22 & 0.02 & 0.08 & -0.28 & -0.07 & -0.05 & 0.14 & 0.17 & 0.05 \\
\hline Lithuania & -0.09 & -0.17 & -0.19 & -0.19 & -0.10 & -0.20 & -0.20 & -0.24 & -0.24 & -0.26 \\
\hline Malta & 2.68 & 1.90 & 2.40 & 2.53 & 1.77 & 1.51 & 1.54 & 1.76 & 1.82 & 1.57 \\
\hline Romania & -0.67 & -0.69 & -0.62 & -0.60 & -0.71 & -0.76 & -0.76 & -0.72 & -0.72 & -0.73 \\
\hline Slovakia & -0.16 & -0.34 & -0.18 & -0.14 & -0.36 & -0.44 & -0.43 & -0.33 & -0.32 & -0.38 \\
\hline Slovenia & 1.86 & 1.26 & 1.70 & 1.79 & 1.09 & 0.69 & 0.71 & 1.01 & 1.05 & 0.83 \\
\hline constant & 86.62 & 170.84 & 79.26 & 70.97 & 245.94 & 230.07 & 223.92 & 387.96 & 400.82 & 429.62 \\
\hline
\end{tabular}

The figure for the constant - the exponential of the estimated coefficient - indicates the estimated income of a person with characteristics described by the omitted categories in $€$. The figures for the dummy variables indicate the ratio of income against the omitted category. Bold figures relate to significant coefficients at 10 per cent or less. 
OLS estimation results: stayers' earnings, various selection correction terms, language skills considered

\begin{tabular}{|c|c|c|c|c|c|c|c|c|c|c|}
\hline \multirow{2}{*}{$\begin{array}{l}\text { Dependent variable: } \\
\log \text { income, } €\end{array}$} & \multicolumn{2}{|c|}{ (1) } & \multicolumn{2}{|c|}{ (2) } & \multicolumn{2}{|c|}{ (3) } & \multicolumn{2}{|c|}{ (4) } & \multicolumn{2}{|c|}{ (5) } \\
\hline & coeff. & (s.e.) & coeff. & (s.e.) & coeff. & (s.e.) & coeff. & (s.e.) & coeff. & (s.e.) \\
\hline eu language, visited & $0.1985^{*}$ & $(0.1024)$ & $0.2213^{* *}$ & $(0.1019)$ & $0.2359^{* *}$ & $(0.1015)$ & $0.2383^{* *}$ & $(0.1015)$ & $0.2753^{\text {*** }}$ & $(0.1016)$ \\
\hline eu language, other & 0.0389 & $(0.0499)$ & 0.0543 & $(0.0493)$ & 0.0719 & $(0.0486)$ & 0.0731 & $(0.0484)$ & 0.0923 ** & $(0.0470)$ \\
\hline part-time job & $-0.3304^{* * * *}$ & $(0.0686)$ & $-0.3369^{* * *}$ & $(0.0677)$ & -0.3115 *** & $(0.0676)$ & $-0.3089^{* * *}$ & $(0.0675)$ & -0.3059 *** & $(0.0645)$ \\
\hline black economy & $0.2159^{* * *}$ & $(0.0982)$ & $0.2185^{* *}$ & $(0.0973)$ & 0.2134 ** & $(0.0948)$ & $0.2162^{* *}$ & $(0.0944)$ & 0.2355 ** & $(0.0921)$ \\
\hline public employer & $0.0898 *$ & $(0.0474)$ & 0.0762 & $(0.0475)$ & 0.0768 & $(0.0471)$ & 0.0758 & $(0.0470)$ & 0.0703 & $(0.0456)$ \\
\hline education: primary & $-0.5717^{* * * *}$ & $(0.0533)$ & $-0.2246^{* *}$ & $(0.0759)$ & -0.2371 ** & $(0.0756)$ & $-0.2114 * *$ & $(0.0748)$ & -0.3392 ** & $(0.0560)$ \\
\hline education: tertiary & $0.2522^{* * *}$ & $(0.0882)$ & $0.1801 * *$ & $(0.0899)$ & 0.1858 ** & $(0.0909)$ & 0.1826 ** & $(0.0911)$ & $0.2149^{\text {*** }}$ & (0.0977) \\
\hline occupation: manual & $0.8604^{* * *}$ & $(0.0675)$ & $0.8292 * *$ & $(0.0674)$ & 0.7908 ** & $(0.0666)$ & 0.7850 *** & $(0.0666)$ & $0.5757^{\text {*** }}$ & $(0.0724)$ \\
\hline occupation: white collar & $0.8366^{* * * *}$ & $(0.0833)$ & 0.7989 & $(0.0823)$ & 0.7327 ** & $(0.0827)$ & $0.7261^{* * *}$ & $(0.0827)$ & 0.4950 *** & $(0.0906)$ \\
\hline occupation: manager & 0.9490 *** & $(0.0823)$ & 0.9318 **; & $(0.0835)$ & 0.8135 ** & $(0.0844)$ & $0.8014 * *$ & $(0.0846)$ & 0.6042 ** & $(0.0909)$ \\
\hline occupation: self employed & $1.0779^{* * *}$ & $(0.1304)$ & $1.0222^{* * *}$ & $(0.1237)$ & 0.9391 ** & $(0.1261)$ & 0.9292 & $(0.1263)$ & $0.7268^{\text {*** }}$ & $(0.1245)$ \\
\hline settlement: rural & 0.0282 & $(0.0500)$ & -0.0049 & $(0.0497)$ & 0.0448 & $(0.0501)$ & 0.0499 & $(0.0500)$ & 0.0028 & $(0.0486)$ \\
\hline settlement: large town & $0.1835^{* * *}$ & $(0.0530)$ & $0.1487^{\text {**: }}$ & $(0.0529)$ & $0.2254^{\text {***}}$ & $(0.0548)$ & 0.2350 k*; & $(0.0549)$ & $0.1421^{\text {*** }}$ & $(0.0528)$ \\
\hline Bulgaria & $-0.5887^{* * * *}$ & $(0.1082)$ & $-0.7546^{* * *}$ & $(0.1058)$ & $-0.6152^{* * *}$ & $(0.1051)$ & $-0.5842^{* * *}$ & $(0.1055)$ & $-0.7277^{\text {*** }}$ & $(0.1083)$ \\
\hline Cyprus & $1.4474^{* * * *}$ & $(0.1258)$ & $1.4127^{* * *}$ & $(0.1223)$ & 1.6089 ** & $(0.1229)$ & 1.6795 **: & $(0.1255)$ & 1.2363 ** & $(0.1404)$ \\
\hline Czech R. & 0.0276 & $(0.1367)$ & $-0.3107^{* * *}$ & $(0.1424)$ & 0.0135 & $(0.1528)$ & 0.0787 & $(0.1556)$ & -0.3659 ** & $(0.1566)$ \\
\hline Estonia & 0.0448 & $(0.1279)$ & -0.1728 & $(0.1295)$ & -0.1989 & $(0.1278)$ & -0.2011 & $(0.1272)$ & -0.1237 & $(0.1266)$ \\
\hline Hungary & $0.3177^{* * *}$ & $(0.1102)$ & 0.0643 & $(0.1120)$ & 0.2903 ** & $(0.1173)$ & $0.3373^{* * *}$ & $(0.1190)$ & 0.0429 & $(0.1190)$ \\
\hline Latvia & 0.0209 & $(0.1167)$ & -0.2636 ** & $(0.1202)$ & 0.0117 & $(0.1275)$ & 0.0707 & $(0.1300)$ & $-0.3417^{\text {*** }}$ & $(0.1370)$ \\
\hline Lithuania & -0.0804 & $(0.1205)$ & -0.1728 & (0.1193) & -0.2008 * & $(0.1181)$ & $-0.2037^{*}$ & $(0.1178)$ & -0.0876 & $(0.1196)$ \\
\hline Malta & $1.2815^{* * * *}$ & $(0.1222)$ & $1.0229^{* * *}$ & $(0.1248)$ & 1.1766 ** & $(0.1219)$ & $1.2154^{* * *}$ & $(0.1224)$ & $0.9643^{\text {*** }}$ & (0.1198) \\
\hline Romania & $-1.0888^{* * * *}$ & $(0.1440)$ & -1.1495 **: & (0.1393) & -0.9491 ** & (0.1394) & -0.9019 **: & $(0.1406)$ & $-1.2067^{\text {*** }}$ & (0.1447) \\
\hline Slovakia & -0.1835 & $(0.1121)$ & $-0.4346^{* *}$ & $(0.1145)$ & -0.2191 * & $(0.1184)$ & -0.1732 & $(0.1198)$ & -0.4632 ** & $(0.1212)$ \\
\hline Slovenia & 1.0352 *** & $(0.1157)$ & $0.7852^{* * *}$ & $(0.1165)$ & 0.9596 ** & $(0.1187)$ & $0.9919^{* * *}$ & $(0.1194)$ & $0.6929^{\text {** }}$ & $(0.1231)$ \\
\hline constant & $4.4277^{\text {*** }}$ & $(0.1209)$ & $5.1337^{* * *}$ & $(0.1610)$ & $4.3413^{\text {** }}$ & $(0.2132)$ & $4.2280^{* * *}$ & $(0.2183)$ & $5.4694^{\text {*** }}$ & $(0.2541)$ \\
\hline lambda $-\mathrm{L}=1$ & & & $-0.6282^{* * *}$ & $(0.1034)$ & $-0.2563^{* * *}$ & $(0.1269)$ & $-0.2501^{* *}$ & $(0.1228)$ & & \\
\hline lambda - M=0 & & & & & -2.2042 ** & $(0.3926)$ & $2.3713^{* *}$ & $(0.3891)$ & & \\
\hline lambda 1 - $\mathrm{L}=1, \mathrm{M}=0$ & & & & & & & & & -0.8023 ** & $(0.1206)$ \\
\hline lambda 2 - $\mathrm{L}=1, \mathrm{M}=0$ & & & & & & & & & -0.7358 & $(0.5412)$ \\
\hline observations & 123 & & $12 ?$ & & 12 & & 12 & & 12 & \\
\hline $\mathrm{R}^{2}$ & 0.6 & & 0.6 & & 0. & & 0. & & 0. & \\
\hline
\end{tabular}

$* * *, * *, *$ denote significance at $1 \%, 5 \%, 10 \%$ respectively. Robust standard errors in parentheses. All explanatory variables are binary. Omitted categories are: full-time job, formal employment, employer in private sector, completed secondary education, occupation unspecified, living in small town, country: Poland. 


\begin{tabular}{|c|c|c|c|c|c|c|c|c|c|c|}
\hline & \multicolumn{2}{|c|}{ (1) } & \multicolumn{2}{|c|}{ (2) } & \multicolumn{2}{|c|}{ (3) } & \multicolumn{2}{|c|}{ (4) } & \multicolumn{2}{|c|}{ (5) } \\
\hline & coeff. & (s.e.) & coeff. & (s.e.) & coeff. & (s.e.) & coeff. & (s.e.) & coeff. & (s.e.) \\
\hline eu language, visited & 0.2139 & $(0.2205)$ & 0.2125 & $(0.2158)$ & 0.2174 & $(0.2175)$ & 0.2159 & $(0.2168)$ & 0.2298 & $(0.2273)$ \\
\hline eu language, other & -0.0710 & $(0.1959)$ & -0.0723 & $(0.1916)$ & -0.0604 & $(0.1964)$ & -0.0619 & $(0.1958)$ & -0.0527 & $(0.2065)$ \\
\hline part-time job & $-0.4755^{* *}$ & $(0.1914)$ & $-0.4763^{* *}$ & $(0.1920)$ & -0.4669 ** & $(0.1904)$ & -0.4656 ** & $(0.1908)$ & $-0.4666^{* *}$ & $(0.2024)$ \\
\hline black economy & 0.0266 & $(0.2146)$ & 0.0259 & $(0.2148)$ & 0.0282 & $(0.2078)$ & 0.0274 & $(0.2070)$ & 0.0333 & $(0.2163)$ \\
\hline public employer & -0.2068 & $(0.1757)$ & -0.2067 & $(0.1766)$ & -0.2599 & $(0.1819)$ & -0.2591 & $(0.1811)$ & -0.2519 & $(0.1855)$ \\
\hline education: primary & $-0.5731 * *$ & $(0.2692)$ & $-0.5797^{*}$ & $(0.3195)$ & -0.5245 & $(0.3349)$ & -0.5145 & $(0.3389)$ & -0.4292 & $(0.3375)$ \\
\hline education: tertiary & 0.3843 & $(0.2481)$ & 0.3845 & $(0.2498)$ & 0.3537 & $(0.2503)$ & 0.3517 & $(0.2508)$ & 0.3601 & $(0.2441)$ \\
\hline occupation: manual & 0.3349 & $(0.2058)$ & 0.3341 & $(0.2053)$ & 0.3035 & $(0.2001)$ & 0.3040 & $(0.2005)$ & 0.3219 & $(0.2180)$ \\
\hline occupation: white collar & $0.7242^{* * *}$ & $(0.2668)$ & 0.7235 *** & $(0.2677)$ & $0.6576^{\text {** }}$ & $(0.2641)$ & 0.6555 ** & $(0.2643)$ & $0.6849^{* *}$ & $(0.2756)$ \\
\hline occupation: manager & $0.5517^{*}$ & $(0.2827)$ & 0.5528 * & $(0.2929)$ & 0.5042 * & $(0.2951)$ & 0.5033 * & $(0.2959)$ & 0.5023 & $(0.3053)$ \\
\hline occupation: self employed & 0.8093 **** & $(0.2058)$ & 0.8095 **; & $(0.2088)$ & 0.7574 ** & $(0.2131)$ & $0.7570 * *$ & $(0.2133)$ & 0.7736 **** & $(0.2340)$ \\
\hline settlement: rural & 0.2602 & $(0.1754)$ & 0.2603 & $(0.1759)$ & 0.2589 & $(0.1740)$ & 0.2625 & $(0.1736)$ & 0.2662 & $(0.1762)$ \\
\hline settlement: large town & 0.1417 & $(0.1515)$ & 0.1412 & $(0.1550)$ & 0.1993 & $(0.1462)$ & 0.2062 & $(0.1460)$ & 0.2058 & $(0.1493)$ \\
\hline Bulgaria & $-1.2311^{* * * *}$ & $(0.4093)$ & $-1.2267^{* * ;}$ & $(0.4201)$ & $-1.1765^{\text {*** }}$ & $(0.4322)$ & $-1.1618^{* * *}$ & $(0.4349)$ & $-1.1735^{\text {***** }}$ & $(0.4829)$ \\
\hline Cyprus & 0.3511 & $(0.5252)$ & 0.3505 & $(0.5290)$ & 0.5679 & $(0.5192)$ & 0.6096 & $(0.5282)$ & 0.6486 & $(0.7140)$ \\
\hline Czech R. & $-1.2132 * *$ & $(0.5194)$ & $-1.2064^{* *}$ & $(0.5490)$ & $-0.9534 *$ & $(0.5648)$ & -0.9132 & $(0.5707)$ & -0.9210 & $(0.8401)$ \\
\hline Estonia & -0.3274 & $(0.3717)$ & -0.3208 & $(0.4339)$ & -0.3539 & $(0.4406)$ & -0.3543 & $(0.4436)$ & -0.4025 & $(0.4067)$ \\
\hline Hungary & -0.0466 & $(0.4956)$ & -0.0429 & $(0.5098)$ & 0.0835 & $(0.5400)$ & 0.1057 & $(0.5467)$ & 0.1108 & $(0.6170)$ \\
\hline Latvia & -0.1057 & $(0.4028)$ & -0.0991 & $(0.4621)$ & 0.0780 & $(0.4897)$ & 0.1064 & $(0.4941)$ & 0.1008 & $(0.6543)$ \\
\hline Lithuania & -0.2214 & $(0.3903)$ & -0.2185 & $(0.4006)$ & -0.2679 & $(0.4033)$ & -0.2689 & $(0.4033)$ & -0.2760 & $(0.4002)$ \\
\hline Malta & $0.9169^{* *}$ & $(0.4409)$ & 0.9224 * & $(0.4734)$ & 1.0003 ** & $(0.4672)$ & $1.0197^{* *}$ & $(0.4698)$ & $1.0047^{*}$ & $(0.5260)$ \\
\hline Romania & $-1.4879^{* * * *}$ & $(0.4035)$ & $-1.4871^{* *}$ & $(0.4077)$ & $-1.3473^{\text {** }}$ & $(0.4383)$ & $-1.3257^{* *}$ & $(0.4435)$ & -1.2882 ** & $(0.5968)$ \\
\hline Slovakia & -0.5991 & $(0.4008)$ & -0.5946 & $(0.4231)$ & -0.4402 & $(0.4447)$ & -0.4204 & $(0.4498)$ & -0.4236 & $(0.5928)$ \\
\hline Slovenia & 0.5403 & $(0.4322)$ & 0.5451 & $(0.4519)$ & 0.7001 & $(0.4673)$ & 0.7176 & $(0.4715)$ & 0.6771 & $(0.5074)$ \\
\hline constant & $5.4434^{* * * *}$ & $(0.4586)$ & $5.4327^{* * *}$ & $(0.5841)$ & 5.9496 ** & $(0.7021)$ & $5.9857^{* * *}$ & $(0.7362)$ & $6.1251^{* * * *}$ & $(0.9272)$ \\
\hline lambda $-\mathrm{L}=1$ & & & 0.0118 & $(0.3418)$ & 0.1909 & $(0.3630)$ & 0.2076 & $(0.4043)$ & & \\
\hline lambda $-\mathrm{M}=1$ & & & & & -0.3855 & $(0.2600)$ & -0.4172 & $(0.2837)$ & & \\
\hline lambda $1-\mathrm{M}=1, \mathrm{~L}=1$ & & & & & & & & & 0.1983 & $(0.7795)$ \\
\hline lambda 2 - $\mathrm{L}=1, \mathrm{M}=1$ & & & & & & & & & -0.4897 & $(0.7806)$ \\
\hline observations & $\overline{93}$ & & 93 & & $\overline{9}$ & & 9 & & 93 & \\
\hline $\mathrm{R}^{2}$ & 0.7 & & 0.7 & & 0. & & 0. & & 0.7 & \\
\hline Hausman $X^{2}$ & 22. & & 24. & & 24 & & 24 & & 19. & \\
\hline $\operatorname{Pr}>x^{2}$ & 0.04 & & 0.02 & & 0.0 & & 0.0 & & 0.12 & \\
\hline
\end{tabular}

$* * *, * * *$ denote significance at $1 \%, 5 \%, 10 \%$ respectively. Robust standard errors in parentheses. All explanatory variables are binary. Omitted categories are: full-time job, formal employment, employer in private sector, completed secondary education, occupation unspecified, living in small town, country: Poland. Hausman test - $\mathrm{H}_{0}$ : The difference between the coefficients of the stayers' and the movers' equation is not systematic (country dummies, the constant, and selection correction terms not included). 


\section{Table 12}

Probit estimation results: selection equations - Eastern European working experience

\begin{tabular}{|c|c|c|c|c|c|c|c|c|c|c|c|c|}
\hline \multirow{3}{*}{$\begin{array}{l}\text { Dependent variables: } \\
\text { working; Eastern Eur. work } \\
\text { experience }\end{array}$} & \multicolumn{4}{|c|}{ Separate probit estimations } & \multicolumn{4}{|c|}{ Seemingly unrelated probit } & \multicolumn{4}{|c|}{ Bivariate probit } \\
\hline & \multicolumn{2}{|c|}{$\mathbf{P}(\mathbf{l}=1)$} & \multicolumn{2}{|c|}{$\mathbf{P}(\mathbf{m}=1)$} & \multicolumn{2}{|c|}{$\mathbf{P}(\mathbf{l}=1)$} & \multicolumn{2}{|c|}{$\mathbf{P}(\mathrm{m}=1)$} & \multicolumn{2}{|c|}{$\mathbf{P}(\mathrm{l}=1)$} & \multicolumn{2}{|c|}{$\mathbf{P}(\mathbf{m}=1)$} \\
\hline & coeff. & (s.e.) & coeff. & (s.e.) & coeff. & (s.e.) & coeff. & (s.e.) & coeff. & (s.e.) & coeff. & (s.e.) \\
\hline couple & 0.8506 *** & $(0.0973)$ & 0.0400 & $(0.1472)$ & 0.8495 *** & $(0.0972)$ & 0.0870 & $(0.1465)$ & $0.3859^{* * *}$ & $(0.1049)$ & 0.0327 & $(0.1462)$ \\
\hline age & & & $0.1364^{* * * *}$ & $(0.0205)$ & & & $0.1184^{\text {** }}$ & $(0.0205)$ & $0.3325^{* * *}$ & $(0.0155)$ & $0.1523^{* * * *}$ & $(0.0254)$ \\
\hline experience & $0.1808^{* * *}$ & $(0.0343)$ & & & $0.1787^{* * *}$ & $(0.0343)$ & & & -0.0109 & $(0.0370)$ & 0.0460 & $(0.0819)$ \\
\hline experience squared & $-0.01433^{* * *}$ & $(0.0033)$ & & & $-0.0141^{* * * *}$ & $(0.0033)$ & & & -0.0149 *** & $(0.0034)$ & -0.0066 & $(0.0071)$ \\
\hline education: primary & $-0.7806^{* * * *}$ & $(0.0514)$ & 0.0023 & $(0.1208)$ & $-0.78055^{* * *}$ & $(0.0513)$ & -0.0542 & $(0.1201)$ & 0.0335 & $(0.0631)$ & 0.0359 & (0.1248) \\
\hline education: tertiary & $0.2660^{* *}$ & $(0.1298)$ & -0.1674 & $(0.2195)$ & $0.2648^{* *}$ & $(0.1296)$ & -0.1451 & $(0.2196)$ & $-0.3968^{* * *}$ & $(0.1484)$ & -0.1814 & $(0.2363)$ \\
\hline settlement: rural & $0.0924 *$ & $(0.0529)$ & -0.0637 & $(0.1048)$ & $0.0924^{*}$ & $(0.0529)$ & -0.0594 & $(0.1047)$ & 0.0481 & $(0.0560)$ & -0.0639 & (0.1047) \\
\hline settlement: large town & 0.0825 & $(0.0561)$ & -0.1798 * & $(0.1093)$ & 0.0825 & $(0.0561)$ & -0.1714 & $(0.1091)$ & 0.0947 & $(0.0592)$ & -0.1634 & $(0.1090)$ \\
\hline Bulgaria & 0.3542 **** & $(0.1037)$ & 0.0793 & $(0.2298)$ & 0.3528 **** & $(0.1036)$ & 0.0854 & $(0.2294)$ & $0.3047^{* * *}$ & $(0.1119)$ & 0.0704 & $(0.2290)$ \\
\hline Cyprus & 0.1124 & $(0.1331)$ & & & 0.1112 & $(0.1330)$ & -5.0553 ** & $(0.1862)$ & $0.7431^{* * * *}$ & $(0.1421)$ & $-5.0333^{* * *}$ & $(0.1869)$ \\
\hline Czech Republic & 0.8506 *** & $(0.1205)$ & 0.0987 & $(0.3063)$ & $0.8484^{* * *}$ & $(0.1204)$ & 0.0967 & $(0.3050)$ & $0.9899^{* * *}$ & (0.1320) & 0.0854 & $(0.3053)$ \\
\hline Estonia & $0.5187^{* * *}$ & $(0.1094)$ & 0.3988 * & $(0.2356)$ & $0.5174^{* * * *}$ & $(0.1091)$ & $0.3963^{*}$ & $(0.2358)$ & $0.6994^{* * *}$ & $(0.1159)$ & $0.4083^{*}$ & $(0.2357)$ \\
\hline Hungary & $0.6264^{* * *}$ & $(0.1066)$ & 0.2231 & $(0.2340)$ & $0.6249^{* * *}$ & $(0.1064)$ & 0.2231 & $(0.2336)$ & $0.6978^{* * *}$ & (0.1143) & 0.2365 & $(0.2347)$ \\
\hline Latvia & $0.6675^{* * *}$ & $(0.1087)$ & 0.5013 ** & $(0.2265)$ & $0.6668^{* * *}$ & $(0.1086)$ & $0.4880 * *$ & $(0.2266)$ & $0.8634^{* * *}$ & (0.1139) & 0.4940 ** & $(0.2267)$ \\
\hline Lithuania & 0.1530 & $(0.1111)$ & $0.6922^{* * *}$ & $(0.2166)$ & 0.1492 & $(0.1111)$ & $0.6821^{\text {*** }}$ & $(0.2165)$ & $0.2037^{*}$ & $(0.1205)$ & $0.6805^{* * * *}$ & $(0.2159)$ \\
\hline Malta & $0.6653^{* * *}$ & $(0.1393)$ & -0.3742 & $(0.4118)$ & $0.6651^{* * *}$ & $(0.1392)$ & -0.3985 & $(0.4116)$ & $0.9787^{* * *}$ & $(0.1362)$ & -0.4046 & $(0.4122)$ \\
\hline Romania & 0.1416 & $(0.1176)$ & 0.3804 & $(0.2336)$ & 0.1402 & $(0.1176)$ & 0.3656 & $(0.2335)$ & $0.5573^{* * *}$ & $(0.1322)$ & 0.4105 * & $(0.2349)$ \\
\hline Slovakia & $0.6282^{* * * *}$ & $(0.1073)$ & $0.6808^{* * * *}$ & $(0.2123)$ & $0.6279^{* * *}$ & $(0.1071)$ & 0.6858 *** & $(0.2121)$ & $0.7201^{* * *}$ & (0.1168) & 0.6793 **** & $(0.2122)$ \\
\hline Slovenia & $0.62411^{* * *}$ & $(0.1102)$ & -0.5244 & $(0.3189)$ & $0.6226^{* * *}$ & $(0.1101)$ & -0.4962 & $(0.3188)$ & $0.8271^{* * *}$ & (0.1171) & -0.4606 & $(0.3230)$ \\
\hline constant & $-0.9897^{* * *}$ & (0.1194) & $-4.8911^{* * * *}$ & $(0.4971)$ & $-0.9845^{* * * *}$ & $(0.1192)$ & -4.5143 *** & $(0.4972)$ & $-7.1697^{* * * *}$ & $(0.3173)$ & $-5.2688^{* * * *}$ & $(0.5661)$ \\
\hline observations & 383 & & 36 & & & & & & & & & \\
\hline log likelihood & -2197 & & -45 & & & & & & & & & \\
\hline rho & -- & & - & & & & & & & & & \\
\hline
\end{tabular}

***, **, denote significance at $1 \%, 5 \%, 10 \%$. Robust standard errors in parentheses. All variables except age, experience and experience squared are binary. Omitted categories are: Completed secondary education, single, living in small town, country: Poland. 
Table 13 OLS estimation results: stayers' earnings, various selection correction terms - Eastern European working experience

\begin{tabular}{|c|c|c|c|c|c|c|c|c|c|c|c|c|c|c|c|}
\hline \multirow{2}{*}{$\begin{array}{l}\text { Dependent variable: } \\
\log \text { income, } €\end{array}$} & \multicolumn{3}{|c|}{ (1) } & \multicolumn{3}{|c|}{ (2) } & \multicolumn{3}{|c|}{ (3) } & \multicolumn{3}{|c|}{ (4) } & \multicolumn{3}{|c|}{ (5) } \\
\hline & coeff. & & (s.e.) & coeff. & & (s.e.) & coeff. & & (s.e.) & coeff. & & (s.e.) & coeff. & & (s.e.) \\
\hline part-time job & -0.3481 & & $(0.0680)$ & -0.3501 & & $(0.0666)$ & -0.3379 & & $(0.0668)$ & -0.3344 & & $(0.0662)$ & -0.3183 & & $(0.0640)$ \\
\hline black economy & 0.1517 & & $(0.0949)$ & 0.1572 & * & $(0.0935)$ & 0.1810 & * & $(0.0923)$ & 0.1686 & * & $(0.0916)$ & 0.1804 & *** & $(0.0884)$ \\
\hline public employer & 0.0568 & & $(0.0465)$ & 0.0460 & & $(0.0465)$ & 0.0191 & & $(0.0478)$ & 0.0317 & & $(0.0464)$ & 0.0392 & & $(0.0449)$ \\
\hline education: primary & -0.6115 & $* * * *$ & $(0.0526)$ & -0.2537 & $* * * *$ & $(0.0739)$ & -0.2918 & $* * * *$ & $(0.0755)$ & -0.2886 & $* * * *$ & $(0.0735)$ & -0.3551 & $* * * *$ & $(0.0534)$ \\
\hline education: tertiary & 0.2835 & $* * * *$ & $(0.0859)$ & 0.2123 & *** & $(0.0862)$ & 0.2672 & **** & $(0.0913)$ & 0.2672 & **** & $(0.0871)$ & 0.2328 & *** & $(0.0933)$ \\
\hline occupation: manual & 0.8019 & $* * * *$ & $(0.0670)$ & 0.7749 & $* * *$ & $(0.0662)$ & 0.7388 & **** & $(0.0657)$ & 0.7189 & $* * *$ & $(0.0652)$ & 0.5352 & $* * * *$ & $(0.0706)$ \\
\hline occupation: white collar & 0.8018 & $* * *$ & $(0.0817)$ & 0.7688 & $* * *$ & $(0.0801)$ & 0.7211 & ***** & $(0.0822)$ & 0.6962 & $* * *$ & $(0.0803)$ & 0.4819 & **** & $(0.0884)$ \\
\hline occupation: manager & 0.8834 & $* * *$ & $(0.0825)$ & 0.8671 & $* * *$ & $(0.0824)$ & 0.7788 & **** & $(0.0838)$ & 0.7582 & $* * *$ & $(0.0834)$ & 0.5516 & $* * *$ & $(0.0887)$ \\
\hline occupation: self employed & 1.0473 & ***** & $(0.1243)$ & 0.9918 & **:* & $(0.1169)$ & 0.9000 & $* * * *$ & $(0.1219)$ & 0.8893 & $* * *$ & $(0.1184)$ & 0.7054 & $* * * *$ & $(0.1192)$ \\
\hline settlement: rural & 0.0181 & & $(0.0496)$ & -0.0129 & & $(0.0491)$ & 0.0148 & & $(0.0515)$ & 0.0333 & & $(0.0497)$ & 0.0102 & & $(0.0485)$ \\
\hline settlement: large town & 0.1709 & $* * *$ & $(0.0512)$ & 0.1464 & $* * * *$ & $(0.0507)$ & 0.2402 & $* * * *$ & $(0.0548)$ & 0.2514 & $* * *$ & $(0.0542)$ & 0.1735 & $* * * *$ & $(0.0538)$ \\
\hline Bulgaria & -0.6557 & "**** & $(0.1063)$ & -0.8362 & **** & $(0.1050)$ & $\begin{array}{l}-0.8059 \\
\end{array}$ & "*** & $(0.1041)$ & -0.8039 & **** & $(0.1034)$ & $\begin{array}{l}-0.7840 \\
\end{array}$ & "**** & $(0.1026)$ \\
\hline Cyprus & 1.3755 & $* * *$ & $(0.1242)$ & 1.3464 & $* * *$ & $(0.1210)$ & & & & 1.6058 & **** & $(0.1283)$ & 1.2905 & **** & $(0.1357)$ \\
\hline Czech R. & -0.0096 & & $(0.1361)$ & -0.3580 & ** & $(0.1413)$ & -0.2271 & & $(0.1427)$ & -0.2066 & & $(0.1418)$ & -0.2925 & *** & $(0.1357)$ \\
\hline Estonia & 0.0419 & & $(0.1219)$ & -0.1963 & & $(0.1246)$ & -0.2211 & * & $(0.1245)$ & -0.2392 & " & $(0.1239)$ & -0.1581 & & $(0.1191)$ \\
\hline Hungary & 0.2653 & *** & $(0.1097)$ & 0.0064 & & $(0.1114)$ & 0.0518 & & $(0.1114)$ & 0.0509 & & $(0.1106)$ & 0.0647 & & $(0.1061)$ \\
\hline Latvia & -0.0124 & & $(0.1172)$ & -0.3094 & ** & $(0.1211)$ & -0.3665 & **** & $(0.1221)$ & -0.3855 & $* * * *$ & $(0.1218)$ & -0.2839 & *** & $(0.1175)$ \\
\hline Lithuania & -0.0654 & & $(0.1232)$ & -0.1724 & & $(0.1222)$ & -0.4647 & **** & $(0.1383)$ & -0.5412 & $* * * *$ & $(0.1430)$ & -0.1393 & & $(0.1471)$ \\
\hline Malta & 1.2705 & $* * *$ & $(0.1173)$ & 1.0072 & **** & $(0.1193)$ & 1.2194 & **** & $(0.1228)$ & 1.2659 & **** & $(0.1240)$ & 1.0422 & $* * * *$ & $(0.1223)$ \\
\hline Romania & -1.1747 & $* * * *$ & $(0.1406)$ & -1.2363 & $* * * *$ & $(0.1362)$ & -1.3186 & $* * * *$ & $(0.1368)$ & -1.3505 & $* * *$ & $(0.1370)$ & -1.2338 & **** & $(0.1375)$ \\
\hline Slovakia & -0.2463 & $* *$ & $(0.1117)$ & -0.4992 & $* * *$ & $(0.1132)$ & -0.6837 & $* * * *$ & $(0.1219)$ & -0.7457 & $* * * *$ & $(0.1239)$ & -0.4591 & $* * *$ & $(0.1254)$ \\
\hline Slovenia & 0.9867 & $* * *$ & $(0.1134)$ & 0.7361 & $* * *$ & $(0.1138)$ & 0.9387 & $* * * *$ & $(0.1178)$ & 0.9716 & $* * *$ & $(0.1186)$ & 0.7450 & **** & $(0.1226)$ \\
\hline constant & 4.5784 & $* * *$ & $(0.1195)$ & 5.3052 & $* * *$ & $(0.1575)$ & 4.8231 & **** & $(0.1823)$ & 4.7779 & **** & $(0.1806)$ & 5.3295 & $* * *$ & $(0.1863)$ \\
\hline lambda $-\mathrm{L}=1$ & & & & -0.6461 & $* * * *$ & $(0.1002)$ & -0.3822 & $\overline{* * * *}$ & $(0.1140)$ & -0.4010 & **** & $(0.1077)$ & & & \\
\hline lambda - $\mathrm{M}=0$ & & & & & & & -2.5226 & $* * * *$ & $(0.4730)$ & 2.7641 & **** & $(0.4738)$ & & & \\
\hline lambda 1 - $L=1, M=0$ & & & & & & & & & & & & & -0.6590 & **** & $(0.0938)$ \\
\hline lambda 2 - $\mathrm{L}=1, \mathrm{M}=0$ & & & & & & & & & & & & & 0.1846 & & $(0.5562)$ \\
\hline observations & & 1266 & & & 1266 & & & 1210 & & & 126 & & & 1266 & \\
\hline $\mathrm{R}^{2}$ & & 0.65 & & & 0.66 & & & 0.65 & & & 0.67 & & & 0.68 & \\
\hline
\end{tabular}

***, $* *, *$ denote significance at $1 \%, 5 \%, 10 \%$ respectively. Robust standard errors in parentheses. All explanatory variables are binary. Omitted categories are: full-time job, formal employment, employer in private sector, completed secondary education, occupation unspecified, living in small town, country: Poland. 
OLS estimation results: movers' earnings, various selection correction terms - Eastern European working experience

\begin{tabular}{|c|c|c|c|c|c|c|c|c|c|c|}
\hline & \multicolumn{2}{|c|}{ (1) } & \multicolumn{2}{|c|}{ (2) } & \multicolumn{2}{|c|}{ (3) } & \multicolumn{2}{|c|}{ (4) } & \multicolumn{2}{|c|}{ (5) } \\
\hline & coeff. & (s.e.) & coeff. & (s.e.) & coeff. & (s.e.) & coeff. & (s.e.) & coeff. & (s.e.) \\
\hline part-time job & -0.1863 & $(0.1864)$ & -0.2360 & $(0.1687)$ & -0.2339 & $(0.1711)$ & -0.2341 & $(0.1701)$ & -0.1823 & $(0.1888)$ \\
\hline black economy & 0.2470 & $(0.2516)$ & 0.2616 & $(0.2419)$ & 0.1953 & $(0.2711)$ & 0.1881 & $(0.2689)$ & 0.2108 & $(0.2946)$ \\
\hline public employer & 0.1158 & $(0.1886)$ & 0.2461 & (0.1966) & 0.2720 & $(0.1976)$ & 0.2795 & $(0.1979)$ & 0.1230 & $(0.1993)$ \\
\hline education: primary & -0.0805 & $(0.2398)$ & -0.8740 ** & $(0.3596)$ & -0.8488 ** & $(0.3584)$ & -0.8949 ** & $(0.3618)$ & -0.0326 & $(0.2716)$ \\
\hline education: tertiary & 0.1101 & $(0.3252)$ & 0.0379 & $(0.3430)$ & 0.1290 & $(0.3666)$ & 0.1457 & $(0.3683)$ & 0.1586 & $(0.4433)$ \\
\hline occupation: manual & 0.9514 ** & $(0.2423)$ & 1.0315 *** & $(0.2358)$ & $0.9615^{* * *}$ & $(0.2622)$ & 0.9615 **; & $(0.2614)$ & $0.9089^{* * *}$ & $(0.2873)$ \\
\hline occupation: white collar & 1.2115 ** & $(0.4006)$ & $1.28599^{* * *}$ & $(0.3800)$ & 1.2075 ** & $(0.4157)$ & $1.2102 * *$ & $(0.4156)$ & 1.1656 ** & $(0.4397)$ \\
\hline occupation: manager & 1.3735 ** & $(0.3670)$ & 1.4669 *** & $(0.3739)$ & 1.3568 ** & $(0.4111)$ & 1.3525 **; & $(0.4081)$ & $1.3126^{* * *}$ & $(0.4436)$ \\
\hline occupation: self employed & 1.3659 ** & $(0.5135)$ & $1.5105 *$ & $(0.4419)$ & 1.4483 ** & $(0.4463)$ & 1.4566 ** & $(0.4432)$ & 1.3168 ** & $(0.5498)$ \\
\hline settlement: rural & 0.0614 & $(0.2227)$ & 0.1936 & $(0.2340)$ & 0.2008 & $(0.2343)$ & 0.2069 & $(0.2344)$ & 0.0542 & $(0.2155)$ \\
\hline settlement: large town & 0.3763 & $(0.2290)$ & 0.6320 ** & $(0.2616)$ & 0.6810 ** & $(0.2818)$ & $0.6986^{* *}$ & $(0.2854)$ & $0.4015^{* * *}$ & $(0.3049)$ \\
\hline Bulgaria & -0.8903 & $(0.6873)$ & -0.2328 & $(0.6641)$ & -0.1896 & $(0.6160)$ & -0.1492 & $(0.6042)$ & -0.8835 & $(0.6865)$ \\
\hline Cyprus & & & & & & & & & & \\
\hline Czech R. & -0.8200 & $(0.9154)$ & 0.1959 & (0.8949) & 0.3998 & (0.8994) & 0.5016 & $(0.9017)$ & -0.7561 & (0.9980) \\
\hline Estonia & -0.4414 & $(0.7504)$ & 0.2050 & $(0.7342)$ & 0.1667 & $(0.7033)$ & 0.2008 & $(0.6896)$ & -0.4704 & $(0.7622)$ \\
\hline Hungary & 0.7125 & $(0.7298)$ & 1.3960 * & $(0.7231)$ & 1.4236 * & $(0.6969)$ & $1.4664^{\text {*** }}$ & $(0.6886)$ & 0.7226 & $(0.7355)$ \\
\hline Latvia & -0.0486 & $(0.6985)$ & 0.7290 & $(0.6819)$ & 0.6530 & $(0.6363)$ & 0.6866 & $(0.6250)$ & -0.1017 & $(0.7014)$ \\
\hline Lithuania & -0.3789 & $(0.6782)$ & -0.0053 & $(0.6302)$ & -0.1608 & $(0.5885)$ & -0.1791 & $(0.5813)$ & -0.4595 & $(0.7613)$ \\
\hline Malta & 2.8121 ** & $(0.7214)$ & 3.5881 ** & $(0.7068)$ & 3.7830 ** & $(0.6947)$ & $3.8582 * *$ & $(0.7000)$ & $2.8965^{\text {*** }}$ & $(0.9651)$ \\
\hline Romania & -0.8616 & $(0.8110)$ & -0.4129 & $(0.7554)$ & -0.4284 & $(0.7195)$ & -0.4080 & $(0.7071)$ & -0.8727 & $(0.8282)$ \\
\hline Slovakia & -0.1223 & $(0.7191)$ & 0.5238 & $(0.7203)$ & 0.4366 & $(0.6983)$ & 0.4571 & $(0.6925)$ & -0.1714 & $(0.7440)$ \\
\hline Slovenia & 0.6184 & $(0.7549)$ & 1.7112 ** & $(0.8433)$ & 1.9339 * & $(0.8700)$ & $1.9454^{\text {*** }}$ & $(0.8536)$ & 0.6815 & $(0.8660)$ \\
\hline constant & 4.3612 ** & $(0.6878)$ & 2.6606 ** & $(0.9259)$ & $3.4764^{\text {** }}$ & $(1.2822)$ & $3.3809^{* *}$ & $(1.3816)$ & $4.8145^{* * *}$ & $(1.5834)$ \\
\hline lambda - L=1 & & & $1.30033^{\text {** }}$ & $(0.4906)$ & $1.3644^{* * *}$ & $(0.4932)$ & 1.5627 & $(0.5540)$ & & \\
\hline lambda $-\mathrm{M}=1$ & & & & & -0.4156 & $(0.4632)$ & -0.3268 & $(0.5217)$ & & \\
\hline lambda 1 - $\mathrm{M}=1, \mathrm{~L}=1$ & & & & & & & & & -0.0393 & $(0.5464)$ \\
\hline lambda 2 - $\mathrm{L}=1, \mathrm{M}=1$ & & & & & & & & & -0.2097 & $(0.8344)$ \\
\hline observations & 6 & & 6 & & 6 & & 6 & & 69 & \\
\hline $\mathrm{R}^{2}$ & 0. & & 0.6 & & 0. & & 0. & & 0.6 & \\
\hline Hausman $X^{2}$ & 14 & & 13. & & 12 . & & 13. & & 13. & \\
\hline $\operatorname{Pr}>\chi^{2}$ & 0.1 & & 0.27 & & 0.3 & & 0.2 & & 0.23 & \\
\hline
\end{tabular}

$* * *, * * *$ denote significance at $1 \%, 5 \%, 10 \%$ respectively. Robust standard errors in parentheses. All explanatory variables are binary. Omitted categories are: full-time job, formal employment, employer in private sector, completed secondary education, occupation unspecified, living in small town, country: Poland. Hausman test - $\mathrm{H}_{0}$ : The difference between the coefficients of the stayers' and the movers' equation is not systematic (country dummies, the constant, and selection correction terms not included). 
Table 15 Predicted stayers' and movers' earnings and returns to foreign experience, by foreign experience status, from various earnings equation specifications, in $€$

\begin{tabular}{|c|c|c|c|c|c|c|c|}
\hline \multicolumn{2}{|c|}{ Earnings equation } & mean diff. & (1) & (2) & (3) & (4) & (5) \\
\hline \multirow[t]{3}{*}{$\mathrm{w}_{\mathrm{S}}$} & $\mathrm{m}=0$ subsample & 192.91 & 193.73 & 194.59 & 195.78 & 195.7797 & 196.33 \\
\hline & $\mathrm{m}=1$ subsample & 258.41 & 256.17 & 263.38 & 271.96 & 271.76 & 266.24 \\
\hline & difference & 65.51 & $62.43^{* * *}$ & $68.79^{* * *}$ & $76.18^{* * * *}$ & 75.98 *** & $69.91 * * *$ \\
\hline \multirow[t]{3}{*}{$\mathrm{w}_{\mathrm{M}}$} & $\mathrm{m}=0$ subsample & 247.11 & 240.43 & 240.50 & 237.28 & 237.37 & 237.56 \\
\hline & $\mathrm{m}=1$ subsample & 331.02 & 313.22 & 313.23 & 314.91 & 314.89 & 314.40 \\
\hline & difference & 83.91 & $72.79^{* * * *}$ & $72.73^{* * * *}$ & $77.63^{\text {**** }}$ & 77.52 & $76.84^{* * * *}$ \\
\hline \multirow[t]{3}{*}{$w_{M}-w_{S}$} & $\mathrm{~m}=0$ subsample & 54.20 *** & $46.70^{* * *}$ & $45.91^{* * *}$ & $41.50^{* * * *}$ & $41.59^{* * * *}$ & $41.23^{\text {*** }}$ \\
\hline & $\mathrm{m}=1$ subsample & $72.61^{* * * *}$ & $57.06^{* * *}$ & $49.85^{* * *}$ & $42.95^{* * * *}$ & $43.13^{* * * *}$ & $48.16^{* * *}$ \\
\hline & difference & $18.41^{* * *}$ & 10.36 & 3.94 & 1.46 & 1.54 & 6.93 \\
\hline \multirow[t]{3}{*}{$\mathrm{w}_{\mathrm{M}}: \mathrm{w}_{\mathrm{S}}$} & $\mathrm{m}=0$ subsample & 1.28 & 1.38 & 1.38 & 1.33 & 1.34 & 1.35 \\
\hline & $\mathrm{m}=1$ subsample & 1.28 & 1.40 & 1.36 & 1.32 & 1.32 & 1.30 \\
\hline & difference & 0.00 & 0.02 & -0.02 & -0.01 & -0.02 & -0.05 \\
\hline
\end{tabular}

*** denotes significance at $1 \%$ (one-sided test of equal means). 


\section{Discussion Papers published since 1999}

\section{4}

Gergely CSORBA: Screening Contracts in the Presence of Positive Net-work Effects MT-DP. 2004/14

K. BOGNÁR - L. SMITH: We Can’t Argue Forever MT-DP. 2004/15

JUHÁSZ A. - SERES A. - STAUDER M.: A kereskedelmi koncentráció módszertana MTDP. 2004/16

Júlia LENDVAI: Inflation Inertia and Monetary Policy Shocks MT-DP. 2004/17

A. FREDERIKSEN -E. TAKÁTS: Optimal Incentive Mix of Performance Pay and Efficiency Wage MT-DP. 2004/18

Péter KONDOR: The More We Know, the Less We Agree: Public Announcements and Higher-Order Expectations. MT-DP. 2004/19

BARANYI B. -BALCSÓK I.: Határmenti együttmúködés és a foglalkoztatás - keletmagyarországi helyzetkép. MT-DP. 2004/20

L.Á. KÓCZY - L. LAUWERS: The Minimal Dominant Set is a Non-Empty Core-Extension. MT-DP. 2004/21

Miklós KOREN: The Law of Two Prices: Trade Costs and Relative Price Variability MT-DP. 2004/22

A. AMBRUS - R. ARGENZIANO: Network Markets and Consumer Coordination. MT-DP. 2004/23

LÓCSEI Hajnalka: A vidéki városi agglomerációk fejlődési pályája. MT-DP. 2004/24

J.D.BROWN - J.S. EARLE - Á. TELEGDY: Does Privatization Raise Productivity?. MT-DP. 2004/25

HÁRS Ágnes: A magyar munkaerő-migráció regionális sajátosságairól MT-DP. 2004/26

2005

GÁCS János: A lisszaboni folyamat: rejtélyek, elméleti problémák és gyakorlati nehézségek. MT-DP. 2005/1

PÉTERI Gábor: Igazodás a piacgazdaság szabályaihoz és megfelelés a helyi elvárásoknak - A városi polgármesterek értékrendje, 2004. MT-DP. 2005/2

SZALAI Ákos: Adóverseny az iparűzési adóban - Az 5000 fő fölötti települések adópolitikája a 2000-es években. MT-DP. 2005/3

Gábor BÉKÉS - Balázs MURAKÖZY: Firm Behaviour and Public Infrastructure: The Case of Hungary. MT-DP. 2005/4

Gusztav NEMES: The Politics of Rural Development in Europe. MT-DP. 2005/5

Gusztav NEMES: Integrated Rural Development - the Concept and Its Operation. MT-DP. 2005/6

JUHÁSZ Anikó -SERES Antal -STAUDER Márta: A kereskedelmi koncentráció tendenciái MT-DP. 2005/7

Hajnalka TARJÁNI: Estimating some Labour Market Implications of Skill Biased Technology Change and imports in Hungary. MT-DP. 2005/8

L. HALPERN - M.KOREN.- Á. SZEIDL: Import and Productivity. MT-DP. 2005/9

Szabolcs LŐRINCZ: Persistence Effects in a Dynamic Discrete Choice Model - Application to Low-End Computer Servers. MT-DP. 2005/10

Péter VIDA: A Detail-free Mediator and the 3 Player Case. MT-DP. 2005/11

László Á. KÓCZY: The Core Can Be Accessed with a Bounded Number of Blocks. MT-DP. 2005/12 
Viktória KOCSIS: Network Asymmetries and Access Pricing in Cellular Telecommunications. MT-DP. 2005/13

István KÓNYA: Economic Development, Exchange Rates, and the Structure of Trade. MTDP. $2005 / 14$

Gábor G. SZABÓ - Krisztina BÁRDOS: Vertical Coordination by Contracts in Agribusiness: An Empirical Research in the Hungarian Dairy Sector MT-DP. 2005/15

Attila AMBRUS: Theories of Coalitional Rationality. MT-DP. 2005/16

Jin-Chuan DUAN - András FÜLÖP: Estimating the Structural Credit Risk Model When

Equity Prices Are Contaminated by Trading Noises. MT-DP. 2005/17

Lawrence UREN - Gábor VIRÁG: Wage Inequality in a Burdett-Mortensen World. MT-DP. 2005/18

Berthold HERRENDORF - Ákos VALENTINYI: Which Sectors Make the Poor Countries so Unproductive? MT-DP. 2005/19

János GÁCS: The Macroeconomic Conditions of EU-inspired Employment Policies. MT-DP. 2005/20

CSATÓ Katalin: Egy fiziokrata: Paul-Pierre Le Mercier de la Rivière. MT-DP. 2005/21

2006

Krisztina MOLNÁR - Sergio SANTORO: Optimal Monetary Policy When Agents Are

Learning. MT-DP. 2006/1

András SIMONOVITS: Social Security Reform in the US: Lessons from Hungary. MT-DP. 2006/2

Iván MAJOR - Why do (or do not) banks share customer information?. A comparison of mature private credit markets and markets in transition. MT-DP. 2006/3

Mária LACKÓ: Tax Rates with Corruption: Labour-market Effects. Empirical Cross-country Comparisons on OECD Countries. MT-DP. 2006/4

György MOLNÁR - Zsuzsa KAPITÁNY: Mobility, Uncertainty and Subjective Well-being in Hungary. MT-DP. 2006/5

Rozália PÁL - Roman KOZHAN: Firms' investment under financing constraints

A euro area investigation. MT-DP. 2006/6

Discussion Papers are available at the website of Institute of Economics Hungarian Academy of Sciences: http://econ.core.hu 